\title{
Sedimentary evolution and stratigraphy of the $\sim 765-740$ Ma Kansuki-Mwashya platform succession in the Tenke-Fungurume Mining District, Democratic Republic of the Congo
}

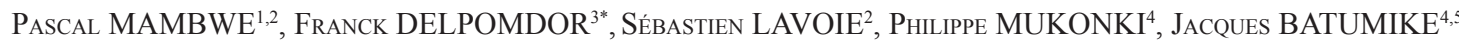 \\ $\&$ PhILIPPE MUCHEZ ${ }^{1}$
}

\author{
${ }^{1}$ KU Leuven, Department of Earth \& Environmental Sciences, Celestijnenlaan 200E, B-3001 Leuven, Belgium; mambwegeo@ \\ gmail.com,philippe.muchez@kuleuven.be. \\ ${ }^{2}$ Tenke Fungurume Mining S.A., Department of Exploration Geology, Route de l'Aéroport, Bâtiment TFM, Commune Annexe, \\ Lubumbashi,Democratic Republic of the Congo; SLavoie@cmoc.com. \\ ${ }^{3}$ Illinois State Geological Survey, University of Illinois at Urbana-Champaign, 615 E. Peabody Dr, Champaign, IL 61820, United \\ States of America; fdelpomd@illinois.edu. \\ ${ }^{4}$ University of Lubumbashi, Department of Geology, 14 Kassapa Road, Lubumbashi, Democratic Republic of the Congo; \\ philmukonki@gmail.com,jbatumike@gmail.com. \\ ${ }^{5}$ ARC Centre of Excellence for Core to Crust Fluid Systems (CCFS) and GEMOC, Department of Earth and Planetary Sciences, \\ Macquarie University, NSW 2109, Australia. \\ * corresponding author.
}

\begin{abstract}
The origin of the Mwashya Conglomerate at the base of the Mwashya Subgroup in the Lufilian Belt is uncertain since it is considered as either a tectonic or as a sedimentary breccia. At Tenke Fungurume Mining District (TFMD) in the Democratic Republic of the Congo, the Mwashya Conglomerate is marked by an iron-bearing polymictic conglomerate embedded between the Kansuki and Kamoya formations. In this paper, the Kansuki-Mwashya platform succession at TFMD was investigated to shed light on the origin of this conglomerate, the depositional evolution and the tectonostratigraphic framework of the platform. Lithofacies analysis revealed that the Mwashya Conglomerate is a periglacial olistostrome, which was formed around 765-745 Ma. A pre-Sturtian age for this conglomerate is supported by the Kamoya Formation, which is here interpreted as a post-glacial cap carbonate sequence. The KansukiMwashya platform succession consists of a protected coastal lagoon adjacent to a tidal flat environment, both bordered by a barrier shoal. This paper concludes that the Kansuki-Mwashya platform succession was driven by rifting pulses, occurring gravity flows on instable slope, superimposed upon the $\sim 750-717$ Ma long-lasting Sturtian glacial period.
\end{abstract}

KEYWORDS: Kansuki-Mwashya platform, Katanga Supergroup, lithofacies analysis, sequence stratigraphy, Sturtian glaciation.

\section{Introduction}

In central Africa (Democratic Republic of the Congo, Zambia and eastern Angola), the Katanga Supergroup rocks record an up to $300 \mathrm{Ma}$ complete Wilson cycle that was initiated at the $>880 \mathrm{Ma}$ intracontinental rifting between the Congo and Kalahari cratons, and ended at the $\sim 573-530$ Ma Lufilian orogeny. The resulting Lufilian Arc forms part of the Pan-African orogenic belts of Africa (Fig. 1; Batumike et al., 2006; Cailteux et al., 2007; Mambwe et al., 2019a). Continental break-up started with the eastward opening of the proto-Mozambique ocean, which propagated westwards into the area of the Zambezi Belt, forming the Zambian Roan RiftBasin. Thereafter it evolved north-westwards into the area of the Lufilian Belt, forming the Congolese Roan Rift-Basin (Porada \& Berhorst, 2000). Both basins widened allowing the development of Afar/Red Sea-type sedimentation in the Roan Rift-Basin, which was marked by a widespread deposition of continental (basal conglomerates, quartzites, feldspathic sandstones and shales) to marine (dominantly carbonates) rocks in the Musonoi Subgroup in the Democratic Republic of the Congo (DRC) (and the Mindola Subgroup, its stratigraphic equivalent in Zambia). These marine conditions continued in the Mines and Fungurume subgroups in DRC and in the Kitwe and Kirilabombwe subgroups in Zambia (François, 1987; Cailteux et al., 2005; Cailteux \& De Putter, 2019).

Around $\sim 765 \mathrm{Ma}$, differential movements of the Congo Craton and the Tanzania block were accompanied by mafic volcanism and induced the north-eastwards extension along preexisting Kibara Belt structures (Cailteux \& De Putter, 2019). The differential movements were associated with the opening of the Nguba rift-basin (former Kundelungu rifting of Porada \& Berhorst, 2000, according to the reviewed nomenclature). The latter rifting was marked by the deposition of at least two distinct syn-rift glaciogenic units, i.e., the Mwashya Conglomerate and Mwale Formation, respectively at the base and top of the Mwashya Subgroup. These formations have been correlated on a lithological basis and geochronology to the $717-660 \mathrm{Ma}$ Sturtian glacial interval (Cailteux et al., 1994; Frimmel et al., 1996; Fölling et al., 2000; Borg et al., 2003; Kampunzu et al., 2005; Batumike et al., 2007; Wendorff \& Key, 2009; Master \& Wendorff, 2011; Rooney et al., 2015; Cailteux \& De Putter, 2019). Recently, Cailteux \& De Putter (2019) have correlated the
Mwashya Conglomerate to the possible $~ 760-740$ Ma Kaigas Formation in the Gariep Belt in Namibia due to its lithology and stratigraphic position below the Sturtian diamictite. Nevertheless, the origin of the Mwashya Conglomerate is highly questionable according to the observed relations: (i) glacial tillites (Vanden Brande, 1944; Cahen, 1947a,b, 1954, 1963), (ii) tectonic friction breccia at the bases of the advancing Katangan nappes (Cailteux \& Kampunzu, 1995; Cailteux et al., 2018), (iii) saltrelated halokinetic deformations, diapirism and extrusions (De Magnée \& François, 1988; Jackson et al., 2003), and (iv) syn-rift alluvial fan debris (olistostromes) derived from an uplifted rift-shoulder platform margin related to rift scarps and thrust-fronts (Wendorff, 2000, 2005a,b; Kennedy et al., 2019).

The Mwashya Conglomerate, which was first described by Vanden Brande (1932), is well exposed at Mwepu-Buseba, Mwashya and Kiswar (Lefebvre, 1978), and along the Congolese and Zambian parts of the Lufilian Arc (Cailteux, 1994; Cailteux et al., 1994, 2007). It consists of a sand- to pebble-sized mudsupported conglomerate including angular to well rounded, smooth and polished clasts of feldspathic sandstones, quartzites, granites, rhyolites, quartz, microclines, tourmalines, silicified oolitic limestones and dolostones (Vanden Brande, 1932, 1944; Cahen, 1954; Lefebvre, 1976). At Tenke Fungurume Mining District (TFMD), the Mwashya Conglomerate is poorly exposed in outcrops, but it is recognized in drillcores. The unit consists of massive and stratified monomictic to polymictic mud-supported conglomerates. However, the nature of these sediments is poorly documented. The purpose of this paper is to reinterpret the sedimentary evolution and stratigraphy of the succession from the Kansuki Formation up to the Kafubu Formation in order to: (1) reconstruct a depositional model on the basis of a lithofacies analysis, (2) understand how changes of sea level controlled the deposition of the carbonate platform system before the onset of the Sturtian glaciation, and (3) discuss the origin of the Mwashya Conglomerate as possibly synchronous with the long-lasting Sturtian-aged Kaigas Formation in Namibia. The paper also discusses mechanisms that controlled the variations of sea level, here regionally coupled with syn-rift tectonism related to the opening of the Nguba rift-basin in DRC (Kennedy et al., 2019; Mambwe et al., 2019a). 


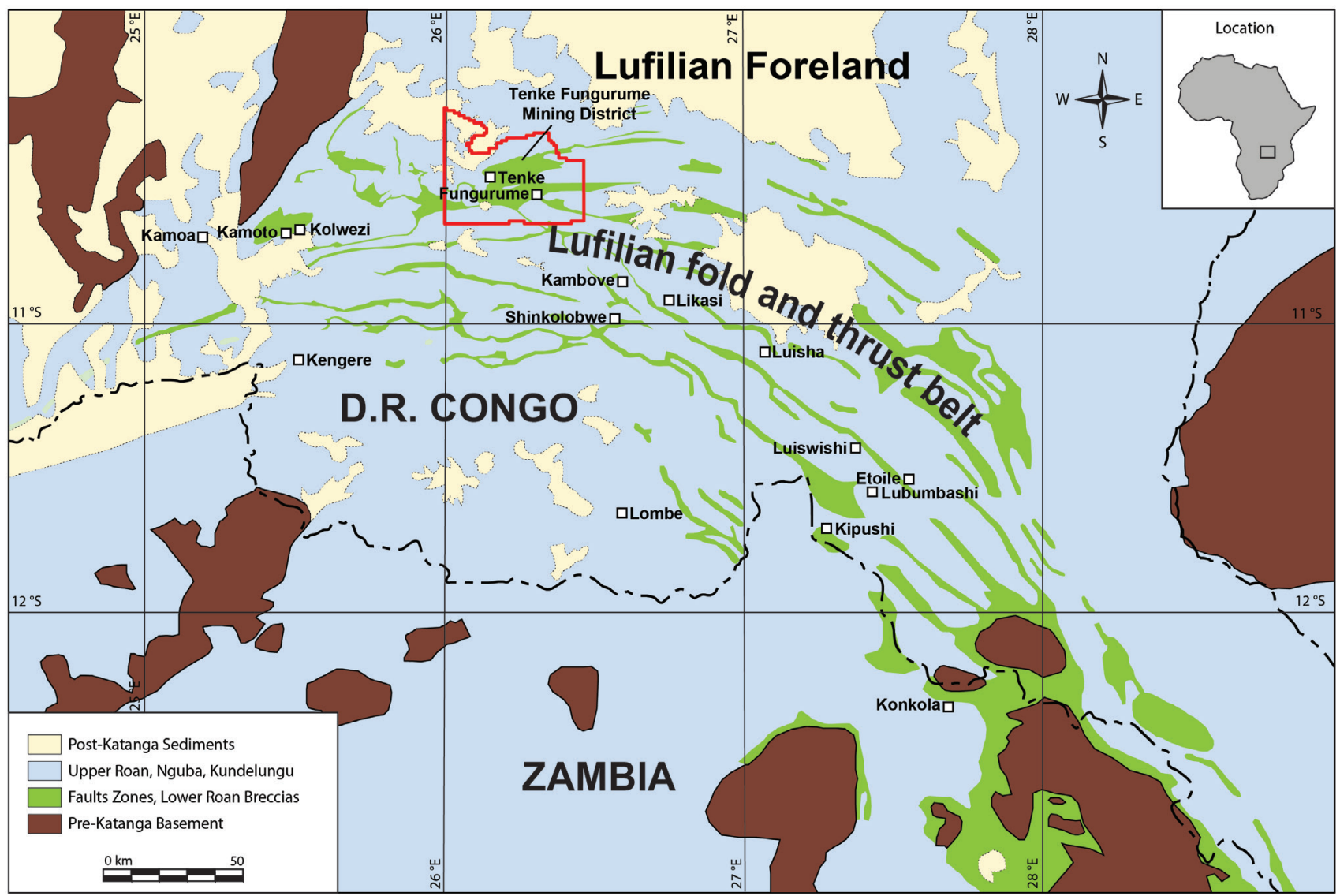

Figure 1. Geological map of the Central African Copperbelt (modified from Cailteux et al., 2018) and location of the Tenke Fungurume Mining District (from Mambwe et al., 2017a).

\section{Geological setting}

\subsection{Lithostratigraphy and geodynamic context}

The Neoproterozoic Katanga Supergroup is a $\sim 15 \mathrm{~km}$-thick metasedimentary succession extending from south-east DRC into northern and north-western Zambia and eastern Angola that was deposited in a $>880$ Ma rifted intracontinental basin starting with the Rodinia continental breakup, forming a $>840-573 \mathrm{Ma}$ wide basin, and ending with the $\sim 573-530$ Ma Lufilian-Zambezi orogeny (Buffard, 1988; Kampunzu et al., 2000; Batumike et al., 2006; Halpin \& Selley, 2010). The Lufilian-Zambezi belt started with the convergence of the Congo and Kalahari cratons that developed northward folding and thrusting (Kampunzu \& Cailteux, 1999; Kipata et al., 2013). Later, large left-lateral strikeslip faults related to the convergence between the Bangweulu block and the Kibara Belt deformed the Katanga Supergroup succession (Kipata et al., 2013). Other significant stages of faulting and thrusting in the Katanga Supergroup were attributed to the post-Lufilian orogenic extension and inversion (Kipata et al., 2013).

In DRC, the lithostratigraphy of the Katanga Supergroup was recently revised by Cailteux \& De Putter (2019), and the proposed subdivision includes, from oldest to youngest (Fig. 2): (1) the Roan Group that comprises from the base to the top, the Musonoï, Mines, Fungurume and Mwashya subgroups, (2) the Nguba Group that comprises from the base to the top, the Muombe and Bunkeya subgroups, (3) the Kundelungu Group that comprises from the base to the top, the Gombela and Ngule subgroups, and (4) the Biano Group that was formerly considered as the top unit of the Kundelungu Group. Two regional stratigraphic marker units, i.e., the diamictites of the Mwale and Kyandamu formations - the latter interpreted as coeval with the Marinoan glaciation ( 635-615 Ma; Master et al., 2005) - occur respectively at the base of the Nguba and Kundelungu groups (Fig. 2). Although, the glacial origin of these diamictites is still debated due to recent observation of submarine gravity sliding of unconsolidated sediments (Kennedy et al., 2019; Twite et al.,
2019) on one hand, and the presence of glaciogenic, glaciofluvial, glaciolacustrine or glaciomarine deposits recognized within these diamictites on the other hand (Binda \& Van Eden, 1972; Wendorff \& Key, 2009; Master \& Wendorff, 2011; Mambwe et al., 2017a). The age of the Mwashya Subgroup is younger than the U-Pb SHRIMP age of $765 \pm 5 \mathrm{Ma}$ and $763 \pm 6 \mathrm{Ma}$ measured on zircon grains from volcanic rocks in the Kansuki Formation (Key et al., 2001; Cailteux \& De Putter, 2019). These ages are coeval with gabbroic rocks from the stratigraphic-equivalent Bancroft and Kanwangungu formations in Zambia giving ages of $752.6 \pm 8.6 \mathrm{Ma}$ and $745 \pm 7.8 \mathrm{Ma}$ (Barron et al., 2003). The youngest depositional age of the Mwashya Subgroup is measured by U-Pb SHRIMP single-zircon dating from altered porphyritic lavas overlying the Mwale Formation that yielded an age of 735 $\pm 5 \mathrm{Ma}$ (Key et al., 2001). Detrital zircon grains from a composite sample of the Mwale Formation yielded a minimum age of 729 $\pm 50 \mathrm{Ma}$, but it was only $88 \%$ concordant (Master et al., 2003). Recent Re-Os dating of carbonaceous shale turbidite of the Kafubu Formation yielded an age of $727.3 \pm 4.9 \mathrm{Ma}$ (Rooney et al., 2015).

\subsection{Geology of the Tenke Fungurume Mining District}

The geology of TFMD was outlined by François (2006) and expanded by Schuh et al. (2012). The eastern and southern parts of TFMD are dominated by a succession of large regional scale folds with alternating anticlines and synclines, while the western part is an assemblage of large mega-fragments and tectonic rafts. The Nguba Anticline is limited to the south by the northwest-aligned Nguba Fault (François, 2006), the Lunda Syncline, the Kapongo Anticline to the north by the Mufufya Syncline that comprise the Fungurume to Mwale succession (Fig. 3). The Konga Anticline, situated between the Mufufya and Kitana synclines and the Katonia Anticline to the north of the Kitana Syncline, consists mainly of Fungurume Subgroup rocks. The Kitana Syncline is the only one in the area that has a normal sequence starting from the Fungurume Subgroup up to the Ngule Subgroup. The Mutaka and Pumpi synclines are located south of the Fungurume Fault and 


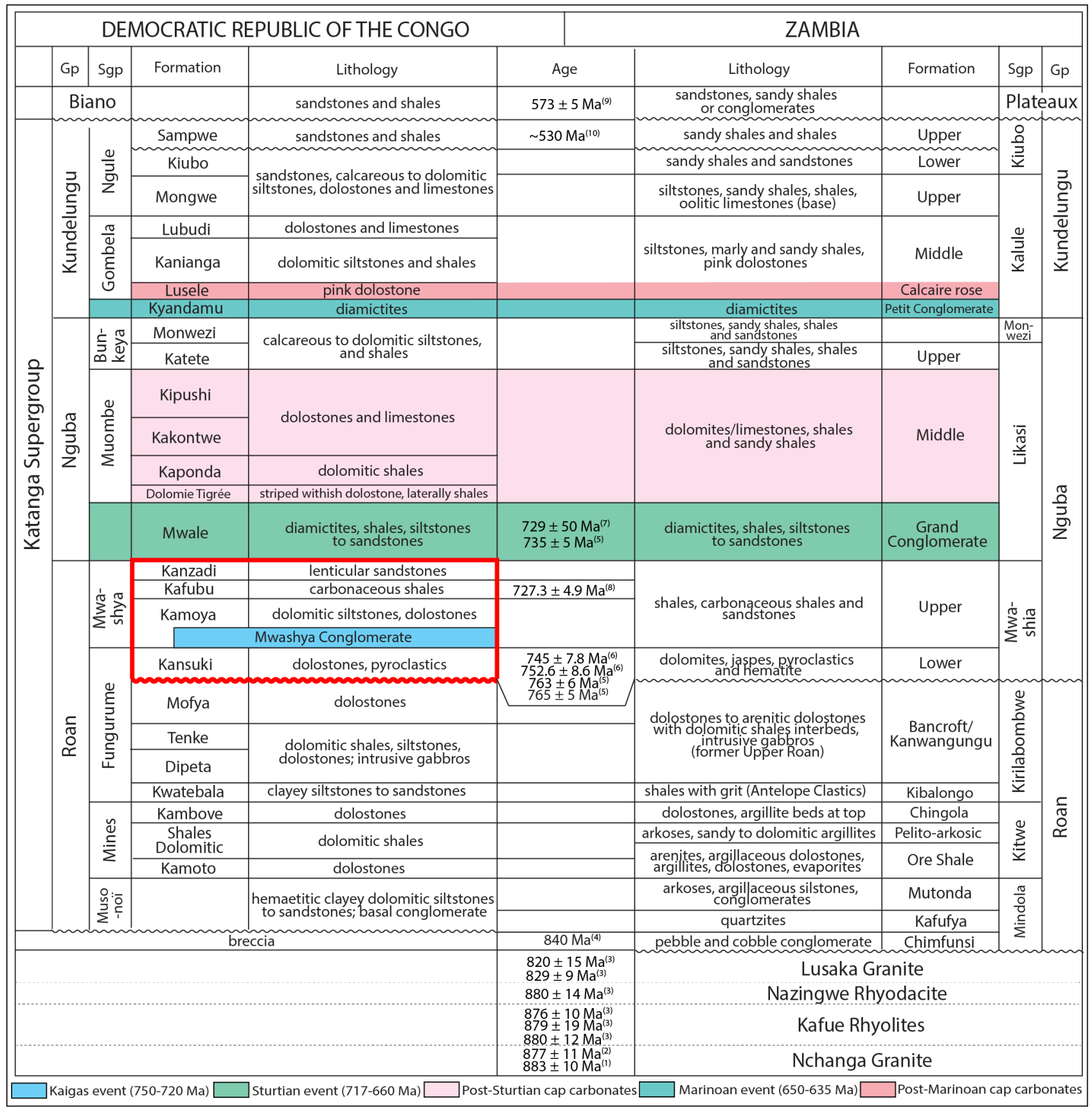

Figure 2. Geochronology and stratigraphic correlation of the Katanga Supergroup in the Lufilian Belt of the DRC and Zambia. Modified from Cailteux et al. (2007). New stratigraphic terminology for the Congolese Lufilian Belt is from Cailteux \& De Putter (2019). Glaciation intervals are marked by the $750-720$ Ma Kaigas, 717-660 Ma Sturtian, and 650-635 Ma Marinoan. Geochronology based on: (1) Armstrong et al. (1999), (2) Jonhson et al. (2007), (3) Halpin \& Selley (2010), (4) Key et al. (2001), (5) Barron et al. (2003), (6) Master et al. (2003), (7) Rooney et al. (2015), (8) Master et al. (2005), (9) John et al. (2004). Abbreviations: Gp, Group; Sgp, Subgroup.

the Pumpi Overthrust Fault, which consist of a normal succession of Nguba and Kundelungu rocks (Fig. 3).

In the western part of TFMD, mega-fragments observed in the Pumpi region form rafts consisting of Nguba and Kundelungu rocks (e.g., Kabwe and Lukonde rafts). In the central part of TFMD, a window into the Roan shows tectonic megabreccias of the Cu-Co-mineralized Mines Subgroup and the Mwale Formation (e.g., Shanika Raft) (Jackson et al., 2003; François, 2006; Mambwe et al., 2017a, 2019b).

In the northern part of TFMD, towards the Katanga foreland (e.g., Plateau de Biano), the geology consists dominantly of Nguba and Kundelungu rocks. This part is marked by a major unconformity at the transition between the Lufilian Arc and its foreland (Alexandre-Pyre, 1967; Kipata et al., 2013; Cailteux \& De Putter, 2019. The uppermost part of the Katanga Supergroup, i.e., the Biano Group, crops out on top of the plateau, which is covered by sand deposits of the Kalahari Group (Alexandre, 2002; Mambwe et al., 2017b).

\section{Materials and methods}

Four recent drillcores from TFMD were logged in detail, representing a total cumulative depth of $1268 \mathrm{~m}$. Most holes started in weathered surface regolith. The holes GCON0060 (250 $\mathrm{m}$ in depth) and GCON0061 (200 $\mathrm{m}$ in depth) were drilled on both flanks of the western extension of the Mufufya Syncline. They intersect a 380.4 m-thick succession composed of Kansuki to Mwale formations (Figs 3 \& 4). The holes GCON0080 (353 $\mathrm{m}$ in depth) and TPST0002 (465 $\mathrm{m}$ in depth) are located on the northern limit of the Pumpi Syncline and the regional Pumpi east-west-oriented thrust fault (Fig. 3). Both holes intercept a 482 $\mathrm{m}$-thick succession composed of Kamoya to Mwale formations. The surface sections intercepted dominantly outcrops of the Mwale Formation and Mwashya Subgroup rocks, and rarely the Kansuki Formation. For each drillcore and outcrop section, the granulometry, facies classification and textural descriptions are given using the carbonate classification of Grabau (1904), 


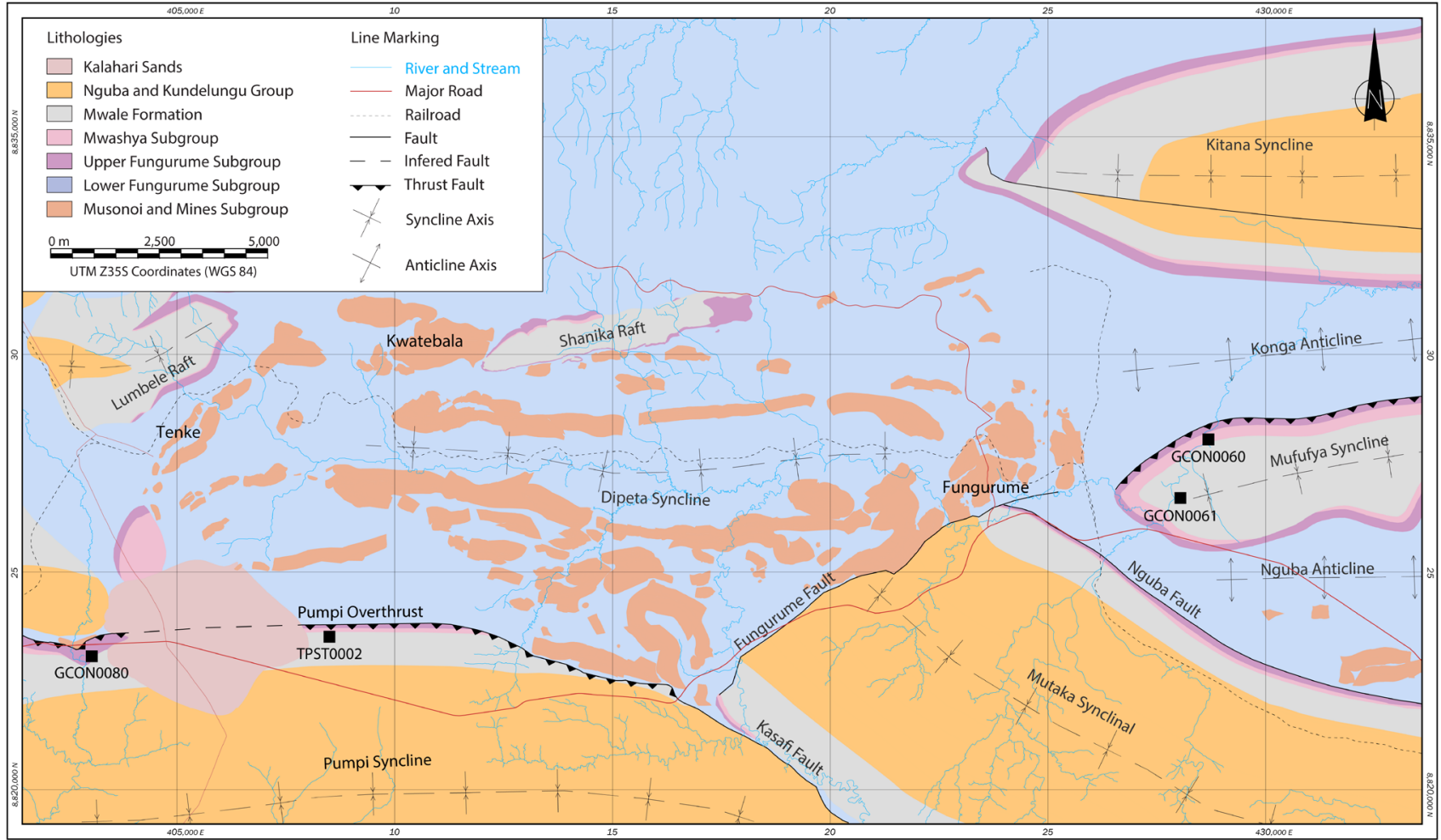

Figure 3. Geological map of TFMD and location of the Mufufya and Pumpi synclines including new surface data from TFM geology exploration (modified from François, 2006).

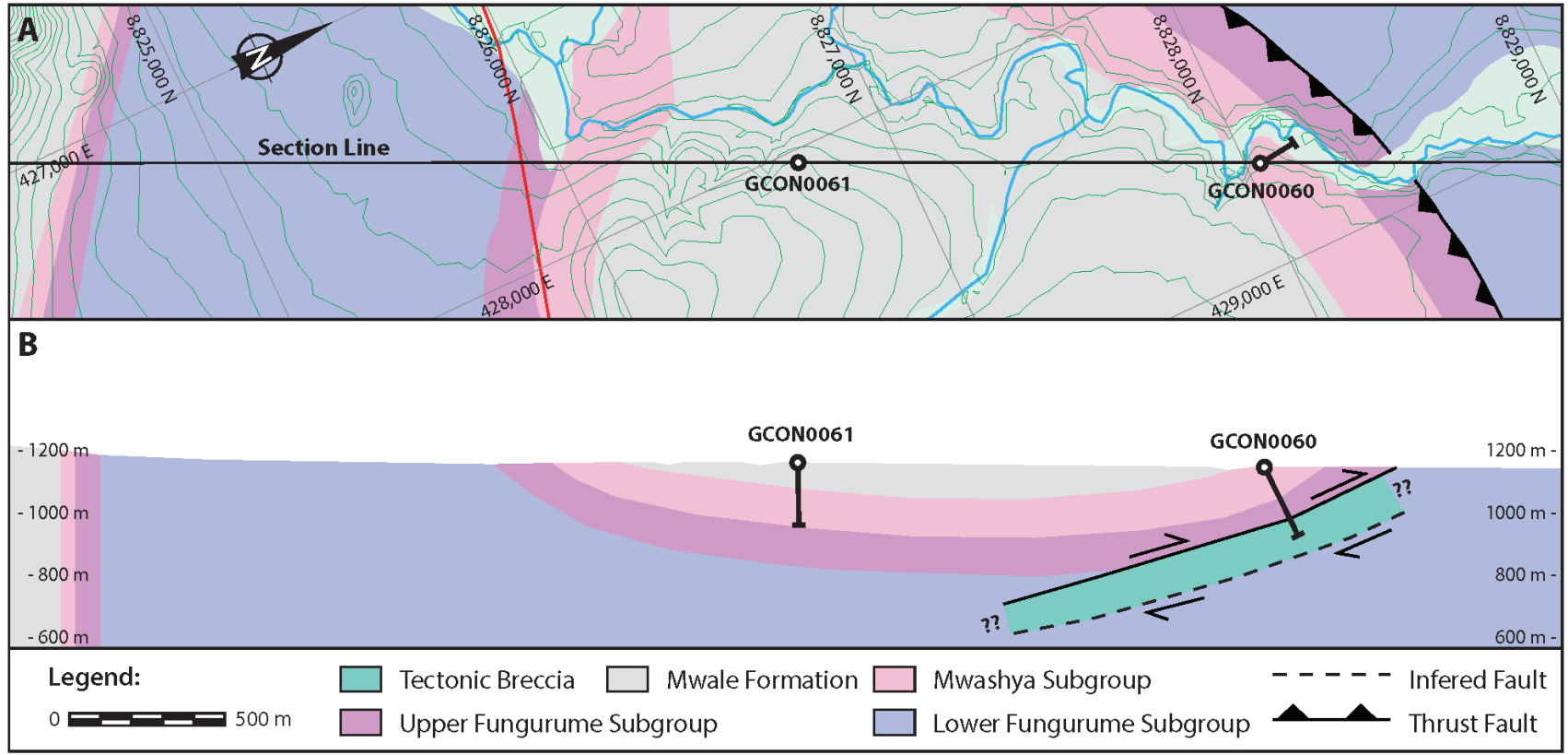

Figure 4. Mufufya Syncline in the eastern part of TFMD: (a) Geological map (after François, 2006), and location of drilled holes (GCON0060 and GCON0061); (b) Geological interpretation of a NE-SW oriented cross section. GCON0060 (Azimuth $\mathrm{N}^{\circ} \mathrm{E}$, dip: $-90^{\circ}$ ) is a vertical hole, while the GCON0061 (Azimuth: $\mathrm{N} 0^{\circ} \mathrm{E}$, dip: $-60^{\circ}$ ) is an inclined hole and projected on the NE-SW cross section.

Dunham (1962) and Embry \& Klovan (1972). Lithofacies analysis was defined as a shallowing-upward hierarchy order of field-feature standard sequence of lithofacies within beds or bedsets. This technique is based on lithological and sedimentary descriptions, stratification, and direct relationship with their depositional processes (Catuneanu, 2006; Flügel, 2010). These lithofacies are grouped into lithofacies associations, which are the basic units for the interpretation of depositional environments. The terminology used in sequence stratigraphy is based on concepts of conformable hierarchy of lithofacies association, bounded by a sequence boundary, that is genetically related to groups of lithofacies deposited by active sedimentary processes within a depositional environment (Catuneanu, 2006; Catuneanu et al.,
2011). Tectonics and climate are thought to be the main driving forces of sea-level changes that, coupled with accommodation, eustatic sea levels and sediment supply, control the development of depositional sequences (Schlager, 1993; Posamentier \& Allen, 1999; Catuneanu, 2006).

\section{Results}

\subsection{New lithological observations}

The Kansuki-Kamoya succession shows particular lithologies at TFMD in the central part of the Nguba rift-basin. In the Mufufya Syncline, the Kansuki Formation was faulted at the base and 
overlies a tectonic breccia. This breccia consists of angular to subrounded carbonate fragments (dolostones and doloarenites), poorly sorted, and locally oriented from $2 \mathrm{~mm}$ to $10 \mathrm{~m}$ in size. The matrix of the breccia displays fine materials (silt and mud in size) with coarse-grained sands of quartz up to $0.5 \mathrm{~mm}$ in diameter and carbonate rocks up to $1 \mathrm{~mm}$ in diameter. The total thickness of this breccia is unknown, but it is at least $96.6 \mathrm{~m}$-thick along the north side of the syncline where it was intercepted by the hole GCON0060 (Fig. 5a). The Kansuki Formation is dominantly characterized by a succession of an alternation of doloarenites, massive and stratified dolostones. These rocks are locally talcose, argillaceous, siliceous and evaporitic. The diagenetic features in the dolostones include larger crystals of dolomite $(1 \mathrm{~cm}$ in size) and stylolites. The coarse-grained detrital quartz grains in the doloarenites are well sorted and show a normal and reverse graded bedding. Centimetre-scale syn-sedimentary normal faults affected only the siliceous dolostones (50 cm-thick) with only millimetre-scale displacement. The latter displays an alternation of light and dark grey beds. The oolitic, pisolitic and stromatolitic dolostones, which occur abundantly at other localities within the Lufilian Belt, do not occur (or have not been recorded) in the studied area.

The Kamoya Formation consists, from base to top, of a polymictic conglomerate, here attributed to the Mwashya Conglomerate, made up of clasts of dolostones, pyroclastic beds, oolitic, pisolitic and stromatolitic dolostones, also present as conglomerates (Figs 5b, c, d). In its upper part, finely laminated carbonaceous shales and mudstones are interbedded with carbonaceous dolostones. The Kamoya Formation disconformably rests through an erosional surface on the underlying Kansuki Formation (Fig. 6). The contact between the Kamoya and Kafubu formations is gradational. On the GCON0061, GCON0080 and TPST0002 holes, the Kafubu Formation is marked by an erosional surface, marking a hiatus, with the Mwale Formation.
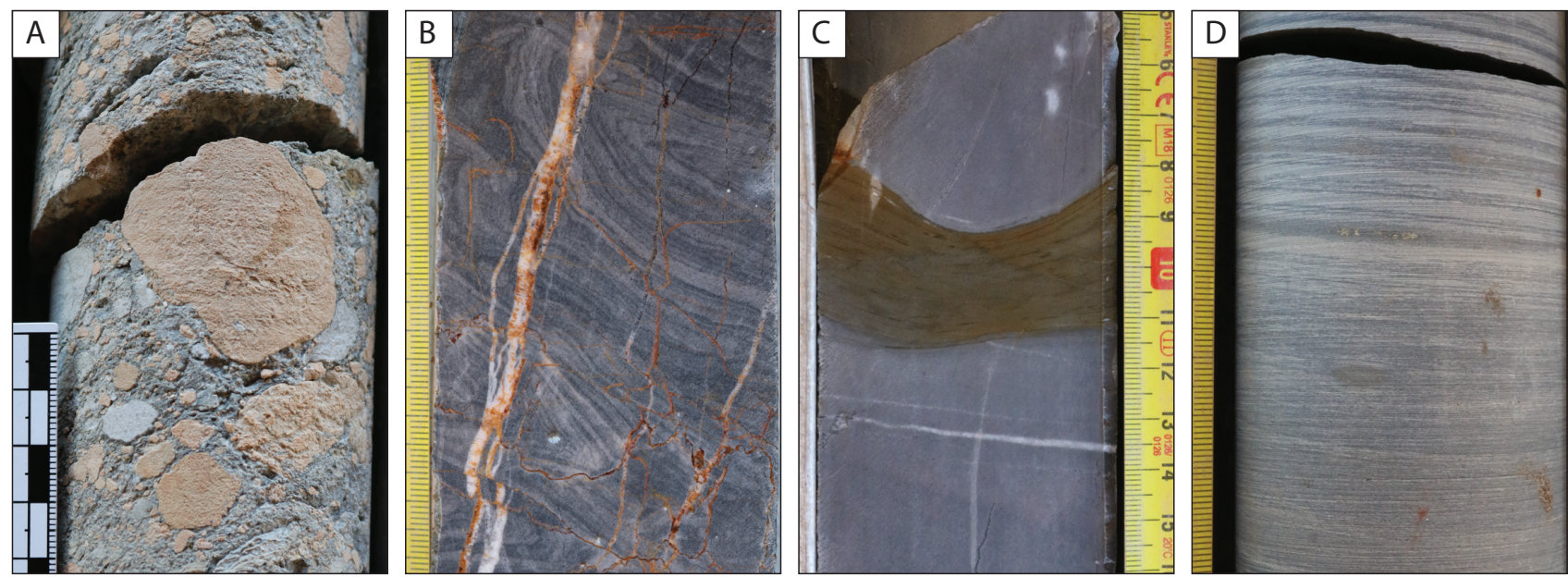

Figure 5. Lithology of the breccia and the Kamoya cap carbonate sequence at TFMD. (a) Tectonic breccia below the Kansuki Formation, present along a thrust fault (GCON0060; see Fig. 4). (b) Dolostone with convolute like-SSDS crosscut by several generations of quartz veins (GCON0060). (c) Massive dolostone with SSDS (GCON0061). (d) Laminated dolostone (GCON0061).
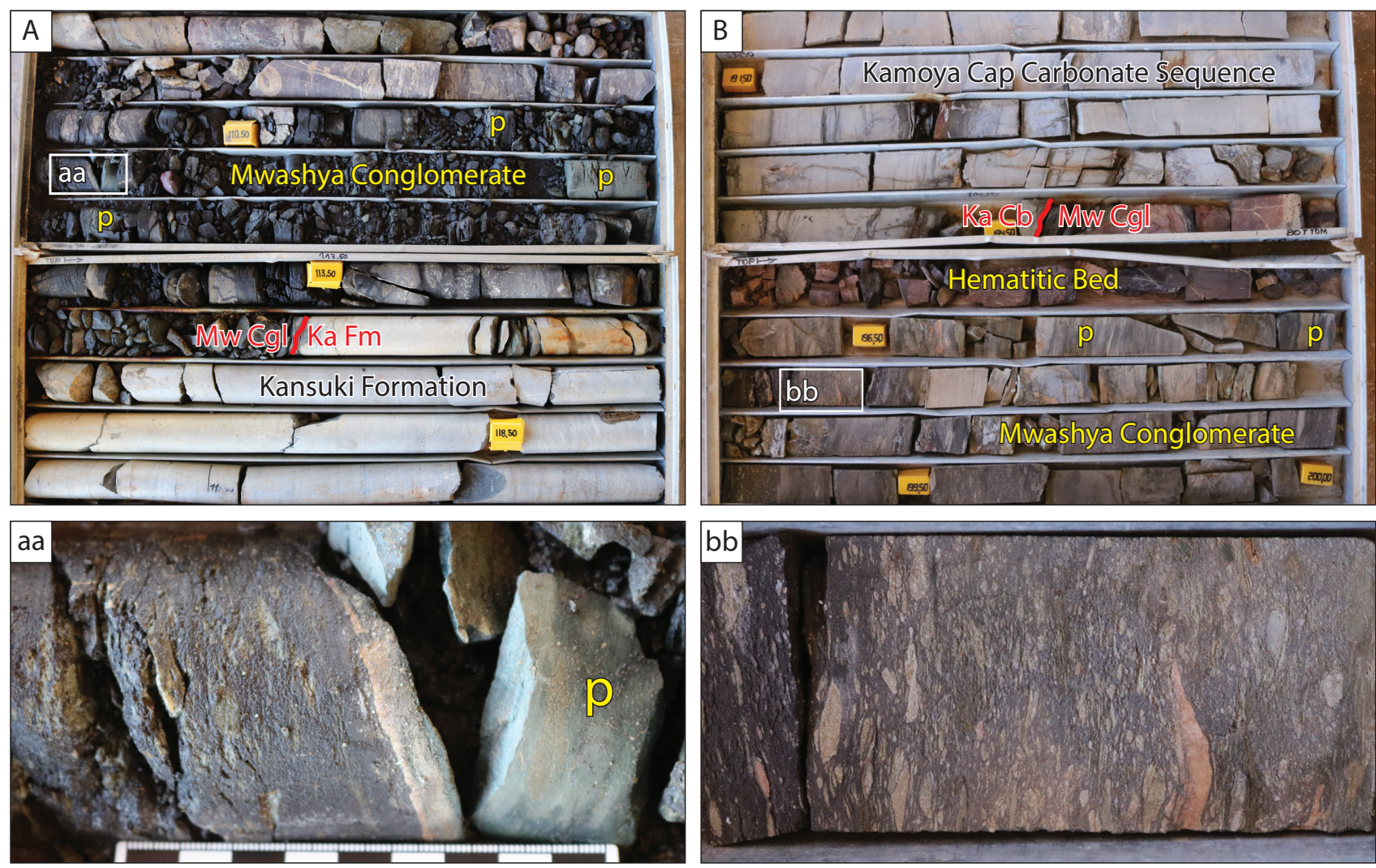

Figure 6. Succession of the Fungurume and Mwashya subgroups at TFMD. (A-A') polymictic conglomerate of the Mwashya Conglomerate interbedded with green chlorite-rich pyroclastic layers (P), overlying massive dolostones of the Kansuki Formation through an erosional surface. (B-B') Kamoya cap carbonate sequence overlying the Mwashya Conglomerate interbedded with pyroclastic layers (P) (GCON0061). 
This atypical contact suggests that the siliciclastic rocks of the Kanzadi Formation as observed at Lubumbashi, Kambove and Mulungwishi regions (see Lefebvre, 1976; Cailteux et al., 2007) are missing. The detrital rocks (shales, siltstones, sandstones) described by Lefebvre $(1976,1978)$ and Cailteux et al. (2007) are absent.

\subsection{Lithofacies analysis and lithofacies associations}

Lithofacies analysis in each hole shown in Figs 8 and 9 allowed the identification of fourteen lithofacies from the Kansuki to Kafubu successions that are grouped into six lithofacies associations. The lithofacies associations are: (1) open-marine shelf margin, (2) mass-movement sediments in an open-marine shelf margin, (3) barrier shoal, (4) back-barrier beach and tidal flat, (5) subtidal lagoon, and (6) intertidal lagoon. These are described and interpreted below.

\subsubsection{Lithofacies association 1 (LFA-1): Open-marine shelf margin}

Description: LFA-1 includes shaley dolomudstones (LF1), massive dolomudstones (LF2), and planar parallel to wavy laminated dolomudstones (LF3). LF1 consists of centimetreto decimetre-thick thin planar parallel laminated to slightly undulating dark grey fine-grained shaley dolomudstones, locally talcose. At the base of the Kamoya Formation, hematitic beds of LF1 are brick red to pale red. LF2 displays decimetre- to metrethick massive fine- to medium-grained, locally sandy, dark to pale grey, hematitic brick red to purple dolomudstones at the base of the Kamoya Formation. Convolute-like structures are also observed in this lithofacies. LF3 is composed of decimetreto metre-thick planar parallel tabular to slightly oblique or slightly wavy laminated fine- to medium-grained, locally sandy or talceous, dark to pale grey, dolomudstones. At the base of the Kamoya Formation, the dolomudstones are hematitic brick red to purple. Decimetre- to metre-long dolostones forming concaveconvex syn-sedimentary fold structures are locally observed. LFA-1 is often associated with pyroclastic rocks.

Interpretation: The open-marine lithofacies association (LFA-1) was deposited on the seaward margin of the carbonate platform. The open-marine carbonate platform margin extends from the barrier shoal lithofacies association (LF5; see below) basinward grading into hemipelagic muds (LF1). The lack of storm-generated structures within LF2 and thin-bedded and laminated structures within LF3 indicates a deposition below storm wave-base. The folding structures, interpreted as convolute and slump bedding, associated with LF2 indicate water-saturated mass displacement of unstable unlithified sediments.

\subsubsection{Lithofacies association 2 (LFA-2): Mass-movement} sediments in an open-marine shelf margin

Description: LFA-2 only includes a matrix-supported conglomerate lithofacies (LF4). LF4 consists of dark purple to greenish-grey poorly sorted massive to stratified monomictic to polymictic conglomerates composed of a fine- to coarse-grained dark grey dolomitic matrix. The conglomerates evolve upward to pervasively sheared and hematitic brick red to purple massive fine materials (silt and mud size) with moderately sorted bed-parallel clasts ( 1 to $5 \mathrm{~cm}$ in length), floating in a small-scale shear zone, of dominant dark grey to grey dolostones. Clasts are bed-parallel, flat and elongated, smooth and polished, subrounded to rounded, and range from sand- to pebble in size. The clasts are mainly composed of dark to pale grey talceous dolostones forming monomictic conglomerates. Locally, a carbonate-cemented polymictic conglomerate, composed of well-rounded sand- to pebble-sized clasts of quartz, quartzite and dolostone, is observed (Fig. 6b). Centimetre-thick layers of greenish volcaniclastic rocks are observed in the polymictic conglomerates. Interlayers of centimetre-thick LF2 and LF3 are common. Bed contacts are sharp and marked by erosion.

Interpretation: The absence of diagnostic pore water pressure structures (flow noses, tiles structures, glaciotectonic laminations, unidirectional folding, clast dispersion tails and fracturing) and features typical of direct ice-contact deposits (boulder pavements, and common presence of striated and glacially-shaped clasts) rejects a direct glacial origin, i.e., tillites. The smooth and polished surfaces of clasts and the clast-roundness demonstrate an active transport, in which significant abrasion increased the edge-rounding and the polishing of clasts. The normally graded sequence contains abundant debris fall sediments that show first coarse-grained particles and then fine-grained material, resembling sediment flows. The graded sequence is overlain by layered drapes of fine sediments devoid of clasts (Benn \& Evans, 2010). The autochthonous nature and internal shape of the clasts in a ductile deformed matrix, as observed in LF4, are interpreted as a carbonate-platform-derived "en-masse" transport formed by a liquefaction and fluidization process inducing the stretching of the sediments along the direction of flow (Flores, 1955; Hsü, 1974; Condie, 2005; Ogata et al., 2014; Festa et al., 2016). Such transport is common in olistostromes, block sliding or debris flow sediments (Ogata et al., 2014; Festa et al., 2016).

\subsubsection{Lithofacies association 3 (LFA-3): Barrier shoal}

Description: LFA-3 includes only oolitic dolopackstones and dolograinstones (LF5; Figs 7a, b). LF5 consists of centimetrethick tightly packed pale grey stratified oolitic dolopackstones, locally dolograinstones when the matrix consists of a whitish dolomitic cement. The matrix is composed of a fine-grained, grey dolomite. Oolites are predominantly up to $1 \mathrm{~mm}$ in diameter, spherical to ovoid concentric and micritic. Dark-coloured silicified oolites are locally observed. The contacts are planar to irregular and sharp with LF3 and LF6 (see below). The contact with LF4 is not observed.

Interpretation: Barrier shoal lithofacies association (LFA-3) was deposited in the near outer margin of a platform environment,
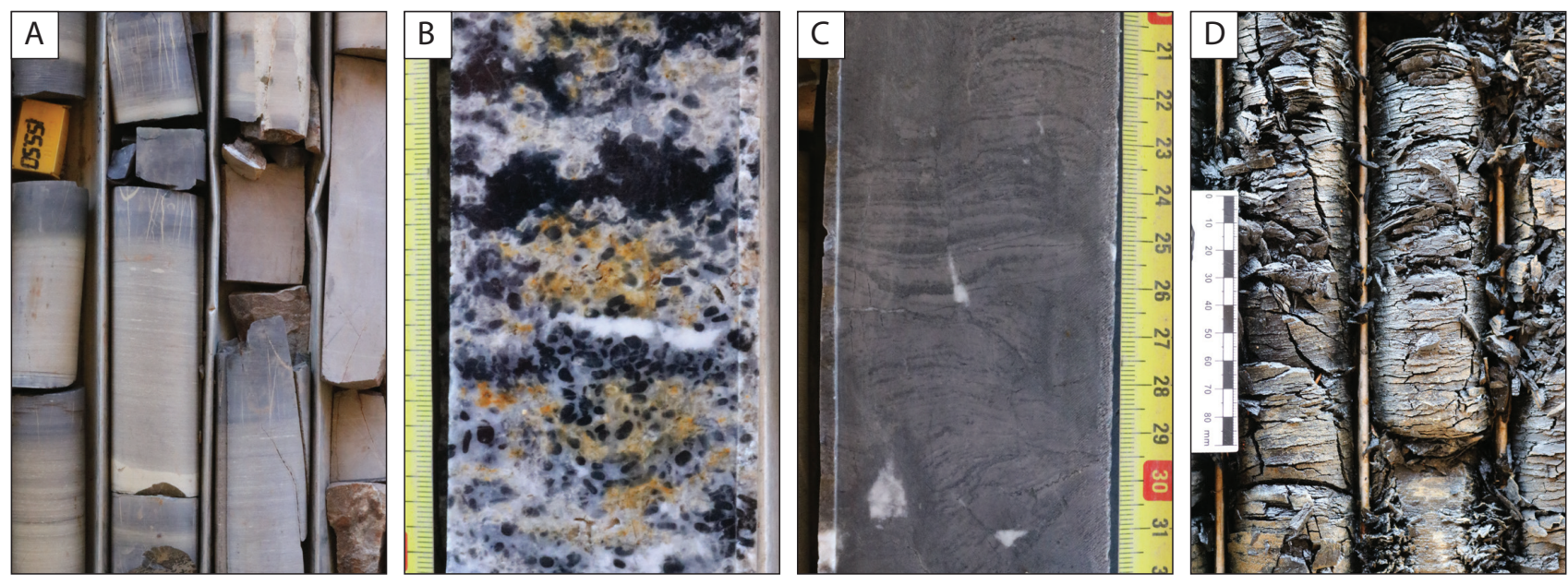

Figure 7. Lithofacies associations in the Mwashya Subgroup. (a) Dolograinstone and (b) oolitic dolopackstone (LF5) in the barrier shoal in the Kamoya Formation (GCON0061). (c) Stromatolitic doloboundstone (LF6) in the back-barrier and tidal fat in the Kamoya Formation (GCON0060 and GCON0061). (d) Shaley dolomudstone (LF12) in the intertidal lagoon adjacent to tidal flat developed in the Kafubu Formation (TPST0002). 
separating the protected lagoon to open-marine environments. The micritic and concentric microfabrics and the abundance of oolites indicate high-energy shallow-water marine environments (Flügel, 2010). The bedding, forming widespread sheet-like oolitic dolopackstones/dolograinstones (LF5), indicates that the oolites were deposited on a fair-weather and wave-agitated shoreface top facing the shelf margin (Wanless \& Tedesco, 1993).

4.2.4. Lithofacies association 4 (LFA-4): Back-barrier beach and tidal flat

Description: LFA-4 includes stromatolitic doloboundstones (LF6; Fig. 7c), pisolitic dolograinstones (LF7), doloarenites (LF8), and planar tabular to cross-bedded dolomudstones (LF9). LF6 displays centimetre- to decimetre-scale grey irregular Lateral Linked Hemispheroids-type stromatolitic doloboundstones. Stromatolitic structures are planar to wavy, forming subhorizontal mats or centimetre-thick unbranched subvertical conical morphologies. LF7 is commonly associated with LF6, and it consists of millimetre- to centimetre-thick grey pisolitic dolograinstones. Pisoids are irregular, asymmetric, and spheroidal to ovoidal. Interparticle pores are dominantly filled by white dolospar crystals. LF8 consists of decimetre-thick, massive to planar or wavy parallel laminated grey, locally beige or pale yellow, medium-grained doloarenites. Thin beds of monogenic conglomerates, composed of subangular to subrounded sandto pebble-sized intraclasts of grey dolomudstones, are locally associated with LF8. LF9 displays centimetre-to decimetrethick finely planar parallel to low angle cross-laminated grey dolomudstones. The contacts with LF7 and LF8 are sharp with local millimetre-scale erosional truncations.

Interpretation: The barrier shoal ends with the deposition of the back-barrier beach lithofacies association (LFA-4), which consists of dominant sandy carbonate materials (LF8) that were down the backside of the barrier, reaching the lagoon. Those sediments were formed under high-energy conditions in which the fair-weather waves and tidal-induced currents, as evidenced by LF8, rework and transport the carbonate grains. Planar bedded sandy sediments were formed by washover of the waves, while cross-bedding developed as sediments were washed into the margin of the lagoon (Reineck \& Singh, 1980). Under moderate energy conditions, the crest of the back-barrier shoal was formed by laminated and encrusting, locally domal, cyanobacterial organisms (LF6) that trapped the mud suspension transported by fair-weather waves and tidal-influenced currents. Pisolites lithofacies (LF7), associated with LF6, originated from the transportation of cyanobacterial oncoids from the crest of the back-barrier shoal. The nature of the sediments deposited in the lagoon reveals that black-coloured muds (LF10) have been enriched in organic matter in a shallow and restricted subtidal zone (Stoffers \& Ross, 1979), while tidal-induced mud, locally evaporitic, developed in an intertidal zone.

\subsubsection{Lithofacies association 5 (LFA-5): Subtidal lagoon}

Description: LFA-5 includes only carbonaceous dolomitic shales and dolomudstones, locally nodular (LF10). LF10 consists of a fining-upward sequence from carbonaceous shales to carbonaceous dolomudstones. The carbonaceous shales are centimetre- to decimetre-thick dark-coloured massive to finely planar parallel laminated. The carbonaceous dolomudstones are dominantly massive and contain nodules at the top. Nodules are dominantly composed of dolomite and quartz. Locally, the aggregation of nodules forms chicken-wire structures. The contact with LF11 is gradational.

Interpretation: The subtidal lagoonal lithofacies assemblage (LFA-5) consists of typical finely laminated and thinly bedded muds deposited in a reducing lagoonal bottom environment as evidenced by the carbonaceous materials. Tidal activity is missing due to the fact that the subtidal lagoon remained water filled even at low tide. Changes of salinity occurred in the lagoon, which, under hypersalinity, formed gypsum/anhydrite nodules.

\subsubsection{Lithofacies association 6 (LFA-6): Intertidal lagoon}

Description: LFA-6 includes carbonaceous and dolomitic rhythmites (LF11), heterogeneous and shaley dolomudstones (LF12; Fig. 7d), laminar dolomudstones (LF13), and evaporitic dolomudstones (LF14). LF11 consists of decimetre- to metre- thick rhythmites composed of millimetre- to centimetre-thick irregularly bounded couplets of dark-coloured carbonaceous dolomitic shales and dark grey shaley dolomudstones, locally talceous. The layer contacts are dominantly slightly undulated to sharp. The contact with LF12 is sharp. LF12 displays a centimetre- to decimetre-thick massive grey, fine-grained to shaley dolomudstones, locally talceous. The contact with LF13 is gradational. LF13 is characterized by centimetre- to decimetrethick finely planar parallel to cross-laminated grey dolomudstones. It is locally associated with monogenic conglomerates composed of subangular to subrounded sand- to pebble-sized intraclasts of grey dolomudstones. LF14 consists of centimetre- to decimetrethick pale grey massive to laminar dolomudstones, locally silicified, composed of dolomitic pseudomorphs after evaporites forming nodular and chicken-wire structures. The contact between LF14 and LF13 is gradational.

Interpretation: The lithofacies association 6 is interpreted as the intertidal zone of a lagoon adjacent to a tidal flat environment. This zone is classically divided into barren zone, marsh and salt pans (Reineck \& Singh, 1980). In our study, the barren zone and marsh are grouped, and they form a transitional zone that extents from the lowest intertidal level up to the highest intertidal level in a salt pan environment. The transition zone was marked by muddier sediments toward the lagoonal bottom environment, as evidenced by the interlayered carbonaceous rhythmites of LF11, evolving landward into carbonate muds and sands (LF12 and LF13) on the margin of the salt pan environment. Due to the moderate amount of muds, LF12 records the transition between the lower and middle part of the intertidal zone. LF13 records the deposition of tidally-influenced laminated muds, which were formed by trapping and binding of fine-grained carbonate sediments by cyanobacteria in the intertidal zone of the lagoon. The carbonate muds with clasts of gypsum/anhydrite crystals and nodules and chicken-wire anhydrite (LF14) are interpreted to have been deposited in the salt pan, here considered similar to sabkha sediments, on the upper part of the intertidal zone and the supratidal zone of the lagoon.

\subsection{Lithofacies successions}

Sequence stratigraphy analysis proposed in this paper is representative of the deposition of the Kansuki, Kamoya and Kafubu succession at TFMD (Figs 8, 9). The sequence stratigraphy analysis of platform carbonates is mainly controlled by the changes of sea level and carbonate production. Carbonate sediments show a variety of depth-sensitive lithofacies characteristics (Jones \& Desrochers, 1992; Miall, 2010). The arrangement and distribution of lithofacies associations are described by a shallowing-upward depositional sequence bounded by a sequence boundary surface. The sequences are interpreted as a response to relative sea-level fluctuations that developed up to a few metre-thick cycles of elementary parasequence sets (Spence \& Tucker, 2007). The Kansuki to Kafubu formations record in all drill holes two distinct depositional sequences (DS1 and DS2) that are bounded by a third incomplete sequence (DS3).

\subsubsection{Depositional sequence 1 (DS1)}

The base of DS1 is marked by an erosive surface that precedes a $\sim 96 \mathrm{~m}$-thick tectonic breccia forming a tectonic unconformity (Cailteux et al., 2007; Cailteux \& De Putter, 2019 Mambwe et al., 2019a). The presence of the tectonic breccia is indicating that the base of the Kansuki Formation is probably missing. The similar lithology of the fragments of this breccia with the surrounding rocks (Fungurume Subgroup) and its internal organization with shear structures reflect the transport of faulted and thrusted upper Roan Group sedimentary pile on the basement (e.g., Lower Fungurume Subgroup; Fig. 4) to the north (Jackson et al., 2003). The transport occurred along thrust faults during the Lufilian orogeny (Kampunzu \& Cailteux, 1999; John et al., 2004; Master et al., 2005; Kipata et al., 2013).

DS1 starts with a $\sim 20$ m-thick lowstand system tract (LST) that is marked by the deposition of aggradational stacking patterns of LFA-1 and LFA-4 cycles (parasequence (psq.) $n^{\circ} 1$ to 4; Fig. 8a). LST is bounded by a transgressive surface (TS), which is marked by a ravinement surface located at the onset of a marine transgression. Approximately $15 \mathrm{~m}$-thick retrogradational 

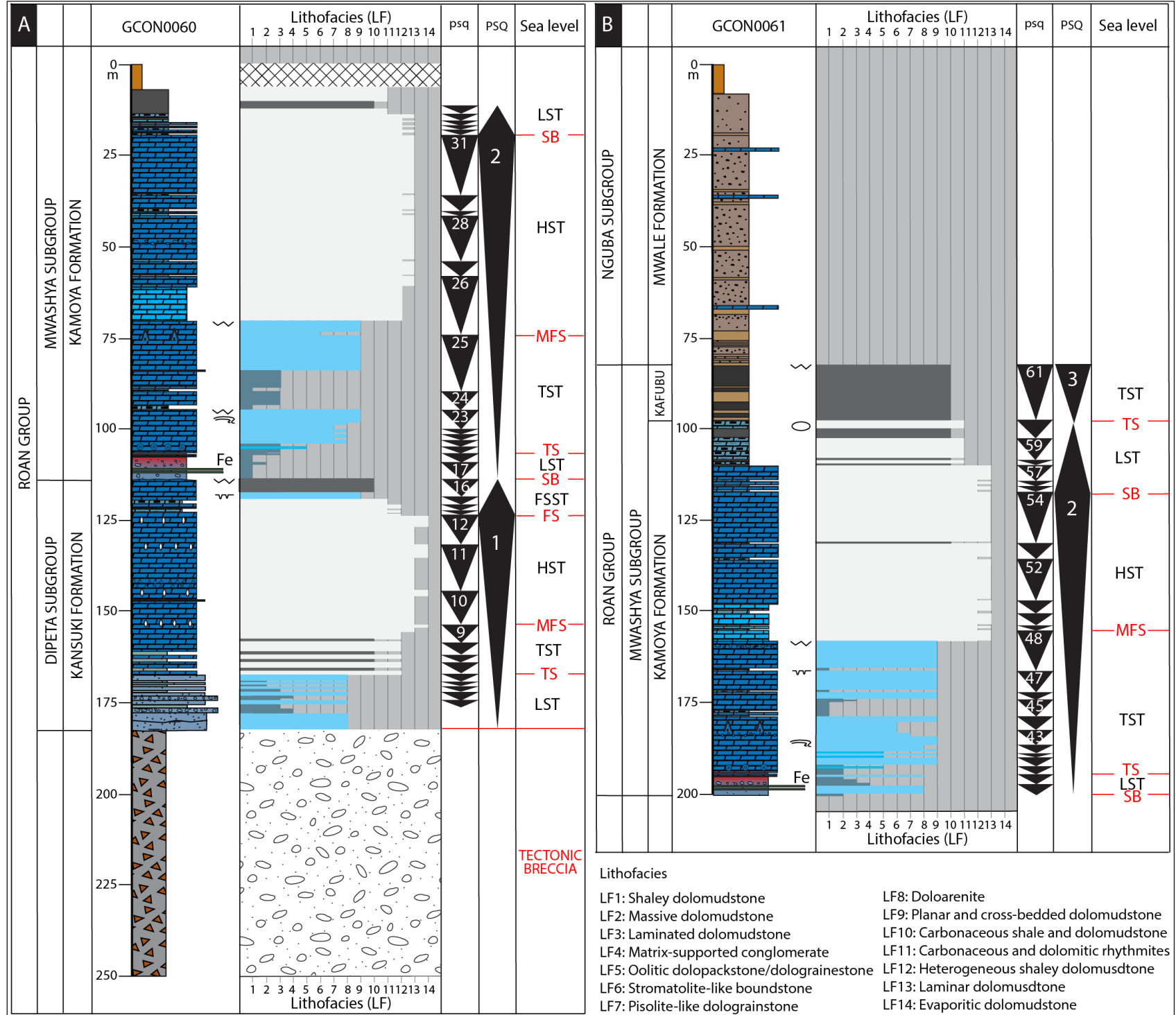

Paleoenvironment

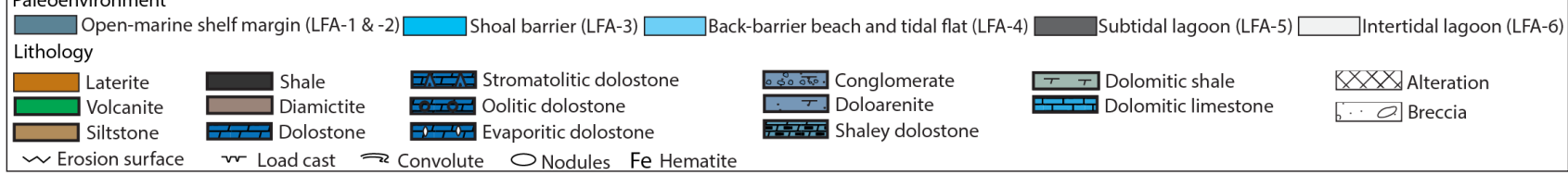

Figure 8. Detailed lithostratigraphy, lithofacies (LF) and sequence stratigraphy (SS) of GCON0060 and GCON0061 drillcores from the Mufufya syncline. Both drillcores show $4^{\text {th }}$-order depositional sequences, which are marked by a transgressive surface (TS) overlain by a transgressive system tract (TST) bounded by a maximum flooding surface (MFS), followed by a highstand system tract (HST). The latter is bounded by a surface boundary (SB) initiating a lowstand system tract (LST). The contact between the Kansuki and Kamoya formations is unconformable and erosive. See text for discussion about the sequence stratigraphy analysis.

stacking patterns of LFA-5 and LFA-6 cycles are identified in psq. ${ }^{\circ} 5$ to 9 , which represents a transgressive system tract (TST) (Fig. 8a). TST is bounded by a maximum flooding surface (MFS) that is marked by the bounding surface between coarsening (LFA1 and LFA-4) and fining (LFA-3 and LFA-6) upward cycles. MFS is overlain by $\sim 35 \mathrm{~m}$-thick aggradational stacking patterns (psq. $\mathrm{n}^{\mathrm{o}} 10$ to 12 ) of evaporitic dolostone (LF14) and lagoonal facies (LF10 to LF13), which is a highstand regressive system tract (HST) (Fig. 8a). This stage is followed by $\sim 10 \mathrm{~m}$-thick lagoonal succession (LF9 to LF13) with local emersion surfaces (psq. $\mathrm{n}^{\circ}$ 13 to 16), which is interpreted as a relative fall of sea level during a falling stage system tract (FSST) (Fig. 8a). DS1 is conformably bounded by a lowstand system tract (LST) that precedes DS2.

\subsubsection{Depositional sequence 2 (DS2)}

The base of DS2 is marked by a sequence boundary (SB) that is identified by a significant erosional unconformity. The elementary parasequences $\mathrm{n}^{\circ} 17$ and 18 (Fig. 8a) and $\mathrm{n}^{\circ} 36$ and 37 (Fig. 8 b) record $\sim 5 \mathrm{~m}$-thick aggradational stacking patterns that are represented by the LFA-1 and LFA-2 successions in atypical marine conditions as evidenced by high concentrations of hematite within carbonate rocks. These elementary parasequence sets represent a lowstand system tract (LST). A transgressive surface (TS) bounds the transition from lowstand to transgressive sea-level stages. A transgressive system tract (TST) progresses with the deposition of two $\sim 35 \mathrm{~m}$-thick distinct aggradational and retrogradational stacking patterns (psq. $\mathrm{n}^{\circ} 19$ to 23 and 24 to 25 in Fig. 8 a, and psq. $n^{\circ} 40$ to 44 and 45 to 48 in Fig. 8 b) of open-marine (LFA-1) to lagoonal (LFA-6) facies. The maximum flooding surface (MFS) is taken as the transition to $\sim 60 \mathrm{~m}$-thick aggradational-progradational stacking patterns (respectively psq. $\mathrm{n}^{\mathrm{o}} 26$ to 31 and 49 to 54 in Fig. 8a, b), dominantly composed of lagoonal facies (LF12 and LF13), that represent a highstand system tract (HST). A microbial reef (LF6) develops at the base of HST (Fig. 8a, b). HST is bounded by a sequence boundary (SB) that is overlain by $\sim 20$ m-thick dominantly aggradational stacking patterns (respectively psq. $\mathrm{n}^{\circ} 32$ to 36 and 55 to 60 in Fig. 8a, b) that are marked by a return to intertidal (LF11 to LF13) to subtidal (LF10) lagoonal facies. 


\subsubsection{Depositional sequence 3 (DS3)}

The base of DS3 is marked by a transgressive surface (TS) comprising a return to $\sim 75 \mathrm{~m}$ LFA-5 sedimentation that is interpreted as a transgressive system tract (TST) (respectively psq. $\mathrm{n}^{\circ} 61,63$ and 68 in Figs 8b, 9a, b). The marine transgression is capped by a maximum flooding surface (MFS) and at least $\sim 35$ m-thick aggradational stacking patterns (psq. $n^{\circ} 69$ to 70 ; Fig. 9b) that represent a highstand system tract (HST). DS3 is conformably bounded by a local erosive surface with the overlying Mwale Formation. This surface recorded erosion or non-deposition of the siliciclastic succession of the Kanzadi Formation.

\subsection{Depositional model}

In our study, the base of DS1 records a fall of sea level followed by a slow rise of sea level that catched up carbonate production within the photic zone with the deposition of open-sea shelf margin sediments (LF2 and LF3), which evolved basinward into hemipelagic muds (LF1) (Fig. 10a). Sedimentation rate exceeded accommodation space increase, which resulted in a transfer of carbonate sediments from the shelf to the deep-water environment, marked by a lateral progradation and probable highstand shedding. The accumulation of unstable unlithified carbonate sediments on the shelf top could have triggered convoluted and gravitational sediments (LF4) to the slope and basin-floor settings (Fig. 10a). The transgression ended by a deceleration of the rising base level that kept up the carbonate production. With the newly created accommodation, a low-energy shallow-water lagoon (LF10 to LF12) developed landward adjacent to a tidal flat environment (LF13), which was protected from the open sea by seaward-shelf barrier shoals (LF5) (Fig. 10b). The base level of the barrier shoal was triggered by extensive winnowing by waves and tidal currents, which were favouring the development of oolites on the flooded shelf top. Laminated and encrusting cyanobacterial mats locally developed in the moderate- to low-energy part of the shelf top. During a highstand normal regression sea-level stage, the development of the carbonate shelf was optimal due to the availability of a large surface area and the low rate of accommodation. The carbonate sediments record the deposition of lagoonal and tidal flat aggrading cycles related to base-level changes on the shelf (Fig. 10c).

A narrow lagoon-edge belt of moderate-energy tidal flat was marked by the development of cyanobacterial mats (LF13). The end of the highstand normal regression sea level was marked by the formation of evaporites (LF14) on the upper part of the lagoon that was starved in the absence of marine circulation over

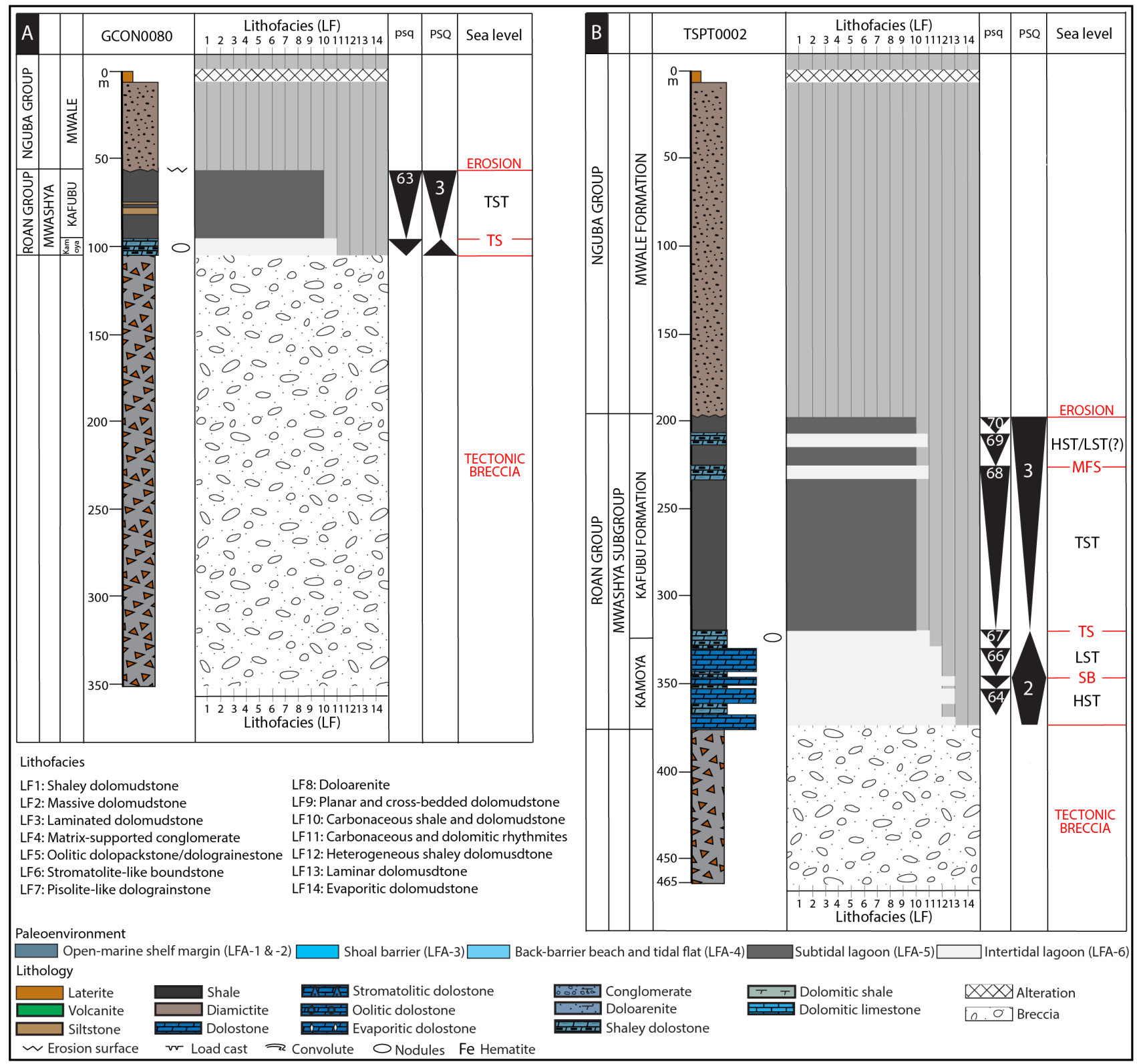

Figure 9. Detailed lithostratigraphy, lithofacies (LF) and sequence stratigraphy (SS) of GCON0080 and TSPT0002 drillcores from the Pumpi Syncline. Two incomplete $4^{\text {th }}$-order depositional sequences are identified in the upper part of the Kamoya and Kafubu formations. The upper part of the Kamoya Formation shows a terminal stage of a highstand system tract (HST) and a lowstand system tract (LST). The Kafubu Formation is marked by a transgressive surface (TS) overlain by a transgressive system tract (TST) bounded by a maximum flooding surface (MFS), followed by a possible highstand system tract (HST). See text for discussion about sequence stratigraphy analyses. 


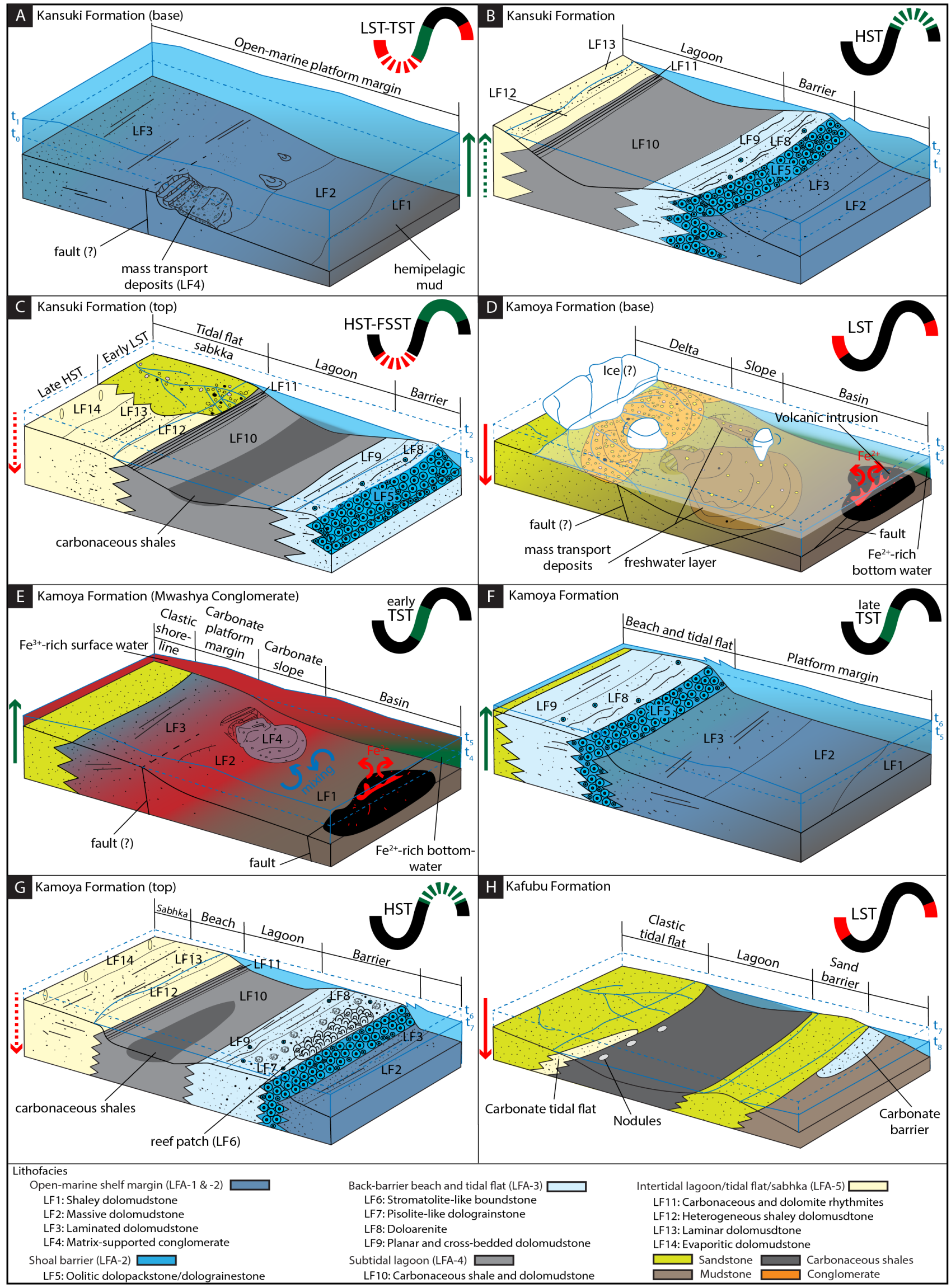

Figure 10. Idealized 3D-model of the platform geometry and lithofacies distribution, coupled with the variation of sea level, of the Kansuki-Mwashya succession at TFMD. (a-c) The sedimentary evolution of the Kansuki Formation records a deposition of open-marine dolomudstones (LF1 to LF3) and local fault-controlled olistostromes (LF4) during a transgressive system tract. This sequence is followed by barrier oolitic dolograinstones/dolopackstones and laminar dolomudstones (LF5 to LF8/9) and lagoon dolomudstones (LF10 to LF13). The sea-level lowstand stage in (c) is characterised by the deposition of sabkha-type evaporitic dolomudstones (LF14) and starved carbonaceous shales (LF10). (d) Deposition of mass transport sediments (LF4), i.e., a polymictic conglomerate facies of the Mwashya Conglomerate during a forced falling sea-level system tract. The fall of sea level is related to a local glaciation. A freshwater layer was derived from the glacially-influenced fluvio-deltaic shoreline. (e) Post-glacial deposition of the Kamoya platform carbonates marked by the turn on of the carbonate factory and the oxidation of ferrous iron in hematite during the initial rise of sea level at the onset of the deglaciation. (f-g) Late marine transgression marked by the development of a seaward barrier shoal (LF5 and LF8/9) and lagoon to tidal flat (LF10 to LF13) muds fringed by an evaporitic sabkha (LF14) during a sea-level highstand stage. (h) Pre-rifting fluvio-deltaic siliciclastic sequence marked by the deposition of lagoon-like carbonaceous shales of the Kafubu Formation at TFMD. 
the shelf due to the barrier shoal (Fig. 10c). However, evaporites also developed in a very shallow water in the upper part of the lagoon during an initial HST, during which carbonate production had exceeded the accommodation and the rise in base level. The highstand normal regression sea-level stage is overlain by a falling stage system tract, as evidenced by the non-deposition of sediments on the platform. This fall of sea level is marked by a ravinement erosion unconformity. With the fall of sea level, the carbonate production is mixed with siliciclastic detritus due to the advancement of the fluvial systems across the shelf. A lowstand system tract (LST) drowned the carbonate shelf and turned off the carbonate factory. The occurrence of shaley dolomudstones and shales (LF1) indicates that terrigenous sediments developed basin-wide across the shelf and within the deep-water setting (Fig. 10e).

The occurrence of monomictic and polymictic conglomerates at the base of the Kamoya Formation is interpreted as the deposition of glacially-induced mass transport sediments, which reworked the Kansuki carbonate platform on the slope of the unstable margin of the platform (see below for discussion; Fig. 10d). Mafic volcanic intrusions (see Lefebvre, 1973) from subaqueous basaltic eruptions from fissures along major fault zones (see Kennedy et al., 2019) expelled ferrous iron in solution in suboxic to anoxic oceanic bottom waters. The sea-level lowstand was followed by a rise of sea level that remobilized the ferrous iron into hematite within the sediments either by seawater turnover, return of the oceanic circulation or upwelling on the open-marine shelf margin and the basin. With the consumption of iron in solution in seawater, sediments developed on the shelf. The transgression decelerated causing the development of carbonate sediments and the formation of barrier setting (LF5, LF8 and LF9) on the shelf top (Fig. 10f). The surplus of carbonate sediments progrades to the shelf edge setting that was marked by unstable unlithified gravity flow sediments (LF4) due to hydraulic instability at the shelf-to-slope edge. The transgression was followed by a slow rise of sea level that developed a seaward barrier (LF6 to LF9) on the wave- and tidally-induced shelf top.

The base-level rises during the HST stage allowed to keep up the carbonate production with a low rate of creation of accommodation. Lagoonal (LF10 to LF12) and tidal flat (LF13) sediments developed on the shelf(Fig. 10g). The return to lagoonal bottom facies (LF10 and LF11) recorded a fall of sea level that initiated the shutdown of the carbonate factory. Evaporite nodules formed during this interval. The transgressive surface at the base of DS3 is interpreted as a drowning unconformity that records a rapid transgression of the carbonate platform. This rapid rise of sea level was marked by an abrupt change of lithology due to the input of siliciclastic material, developing a condensed carbonaceous shale succession, which initiated the shutdown of the carbonate factory or the landward backstepping of the carbonate platform (Fig. 10h). The siliciclastic sedimentation became dominant in the lagoon.

\section{Discussion}

\subsection{Regional implication}

The formation of the Nguba rift-basin was controlled by a combination of competing mechanisms, including magmaticthermal processes and a more erratic plate tectonic regime related to the reorganization of the Congo Craton. These insights were recorded by the relative changes of sea level and the rate of accommodation, which offered to use the sequence stratigraphy within sedimentary successions well constrained in ages such as for the Congolese and Zambian parts of the Lufilian belts. Such sequence stratigraphy analysis has been proposed for the lower and middle parts of the Roan Group and partially investigated for the Mwashia succession in Zambia (see Bull et al., 2011).

At TFMD, the carbonate-dominated Kansuki-KamoyaKafubu formations were accumulated during the $\sim 760-740 \mathrm{Ma}$ breakup in the Zambezi Roan Rift-Basin, that was accompanied by widespread mafic magmatism, and further to the southeast, the rapid opening and subsidence of the Nguba rift-basin (Kampunzu et al., 2000; Porada \& Berhorst, 2000; Key et al., 2001) (Fig. 11). In DRC, the Kansuki Formation was deposited on shallow-water reefal to intertidal margin of the platform, periodically subject to emergence (Cailteux et al., 2007). Recently, the recognition of soft sediment deformation structures indicates that the Kansuki Formation was deposited in an intertidal to supratidal setting (Mambwe et al., 2019a). At TFMD, the distribution of lithofacies and the sequence stratigraphy analysis reveal that the Kansuki Formation developed on a carbonate platform in one single transgressive-to-regressive stage (see DS1 above). Volcaniclastic rocks and/or iron-remobilized hematitic beds from the volcaniclastic material, which frequently developed at the base of the Kansuki Formation (Cailteux, 1983; Cailteux, 1994; Cailteux et al., 2007), are missing in the Kansuki rocks at TFMD (Fig. 11). With the rifting of the newly formed Nguba rift-basin, a rise of sea level caused the accumulation of coarser-grained sediments along the proximal rim of the platform. With the decrease of the thermal subsidence, the production of carbonate turned on initiating the development of a restricted carbonate lagoon bordered landward by a tidal flat and seaward by a barrier carbonate platform. During a sea-level highstand stage, the climax of the carbonate production initiated the formation of lagoon and tidal flat carbonate sediments (Fig. 11). The Kansuki succession was bounded above by a conformable contact that marked the backstepping from lagoonal to open-marine platform margin facies.

In DRC, the Mwashya Subgroup was interpreted as upward cycles of marine carbonate to deltaic clastic rocks that formed as a response to the widening of the sedimentary basin and/or a climate change (e.g., from arid to wet) (Cailteux et al., 2007; Miller, 2013). At TFMD, the Mwashya Subgroup recorded at least two distinct transgressions as evidenced in DS2 and DS3. In DRC, the base of the Mwashya succession comprises a basal conglomerate of the "Mwashya Conglomerate" that records the return of a fluvial discharge from the Kibara Belt or the pre-Kibaran basement to the north of the basin. In Zambia, the Mwashya Conglomerate forms a deep-marine olistostrome, whose clasts were derived from progressive erosion of the Roan platform (Wendorff, 2005a,b). Concomitant extrusions of pyroclastic rocks and lavas were associated with the closing stages of $\sim 765-746$ Ma Naauwpoort/ Devede-Mwashya volcanism (Hoffman et al., 1996; Key et al., 2001; Halverson et al., 2005) (Fig. 11).

Magmatic activity extended in the Gariep Belt and is characterized by the intrusion of the $771 \pm 6$ Ma Lekkersing granite (Frimmel et al., 2001) and the $752 \pm 6 \mathrm{Ma}$ and $741 \pm 6$ Ma felsic volcanic rocks in the Rosh Pinah Formation (Frimmel et al., 1996; Borg et al., 2003) (Fig. 11). As the result of the recognition of a facies for the Mwale Formation in DRC and Zambia interpreted as glaciogenic sediments deposited during the Sturtian glaciation (Cahen, 1954, 1963; Binda \& Van Eden, 1972) and the age younger than $\sim 760-740$ Ma in the Mwashia Subgroup in Zambia (Key et al., 2001), the Mwashya Conglomerate could be correlated with the $\sim 750-720$ Ma Kaigas Formation in the Gariep Belt in Namibia (Frimmel et al., 1996; Fölling et al., 2000; Borg et al., 2003). However, the glacial origin of the Mwashya Conglomerate is highly questionable (see section 5.2.). At TFMD, the Mwashya Conglomerate is laterally replaced by hematitic beds of fine-grained material with sand- to- pebblesized clasts, accompanied by mafic volcanic intrusions, that vertically evolve into mixed siliciclastic-carbonate deposits, which developed during an initial rise of sea level (Fig. 11). Similar to the hematitic beds in the Kansuki Formation, the hematite was the result of remobilization of ferrous iron in bottom waters from volcaniclastic material that was oxidized either by a seawater turnover, a return of the oceanic circulation or upwelling on the open-marine shelf margin and the basin. Seawater had to be oversaturated in calcium, rapidly favouring the formation of oolites on the barrier platform top, followed by the development of lagoonal and tidal flat sediments during a sea-level highstand. Preceding the drowning of the carbonate platform and the deposition of a transgressive sequence of the Kafubu Formation, the Kamoya carbonate platform was marked by a fall of sea level as marked by the deposition of evaporites in the basin. Rocks of the overlying Kafubu and Kanzadi formations were interpreted as (1) deposited in a cold climate and sea-level lowering, which preceded the Sturtian glacial event leading to the deposition of the Mwale Formation (Cahen, 1954, Buffard, 1988; Cailteux et al., 2007) or (2) syn-rift deltaic siliciclastic sequences recording 


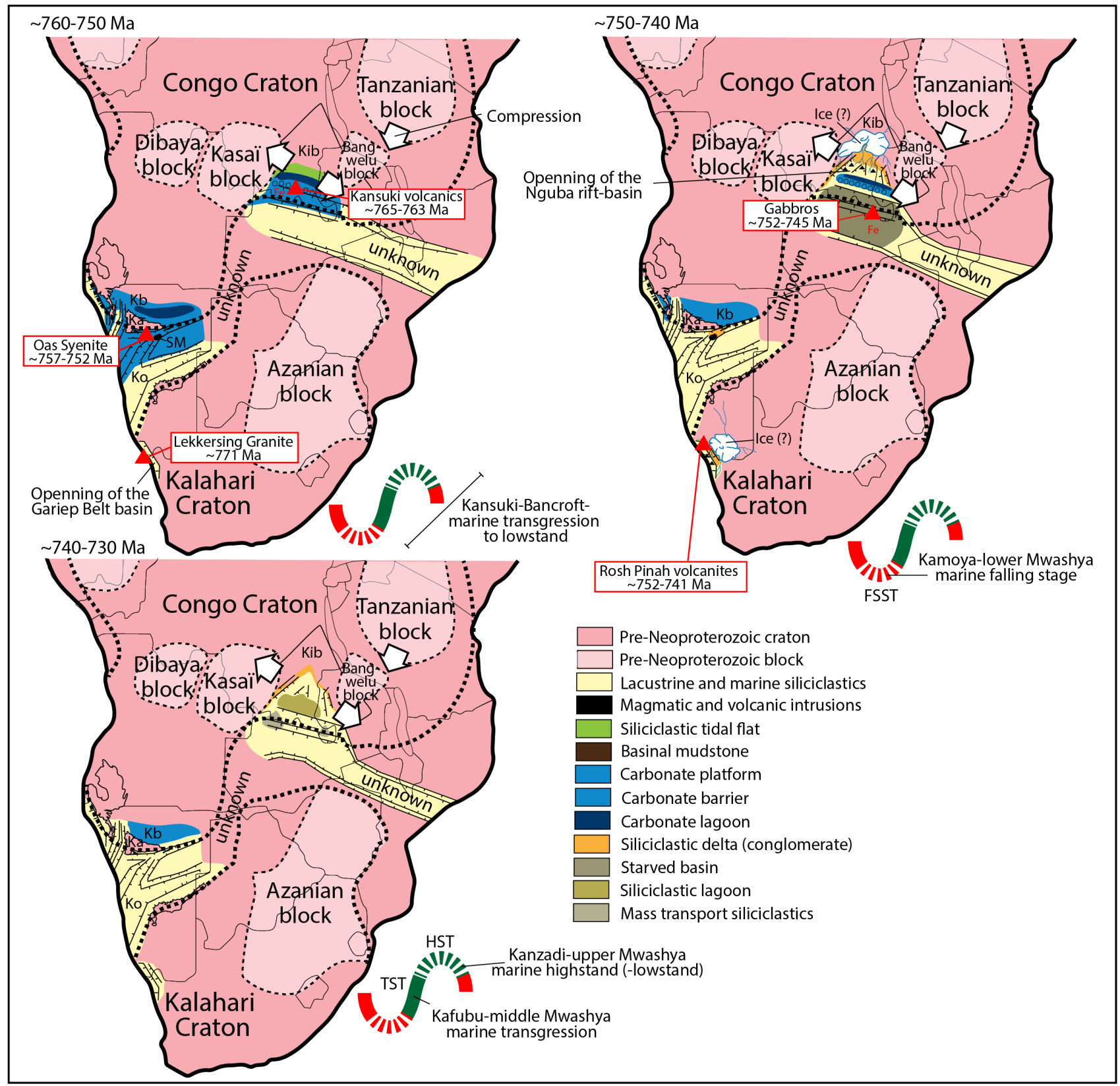

Figure 11. Tectonostratigraphic depositional model of the Lufilian Belt in the DRC and Zambia compared with the Damara and Gariep belts in Namibia (see discussion). Abbreviations: Ko, Khomas Trough; Ka, Kamanjab Montain; Kib, Kibara Belt; Kb, Karibib Platform; SM, Summas Mountain.

the initial phase of rifting of the Nguba rift-basin (Kennedy et al., 2019). Carbonaceous beds of the Kafubu Formation accumulated in less ventilated parts of the basin due to high amount of organic carbon. Associated with the pre- and syn-Sturtian glaciation, a volcanic activity led to the local accumulation of a thick volcanic to volcaniclastic succession within the basin (Kennedy et al., 2019). Similar volcanism occurred in the newly formed Rosh Pinah Basin in the Gariep Belt and laterally in the upper part of the Ombombo Subgroup in the Damara Belt (Frimmel, 2009a,b) (Fig. 11). The overlying arenitic series, preceding the Sturtian diamictites, accumulated on palaeoshore lines along the current margins of the orogenic belt.

The upper part of the Neoproterozoic sedimentary Roan succession records two major tectonostratigraphic sequences that were the result of tectonic remobilization of the Congo Craton. The first tectonostratigraphic sequence strata were conformably capped by a hiatus, as observed at the base of the Kansuki Formation (see Cailteux \& De Putter, 2019), which marked the start of the rifting of the Nguba rift-basin as recorded by volcanic rocks around $\sim 765 \mathrm{Ma}$. The onset of the second tectonostratigraphic sequence, as shown in the Kamoya series, recorded a fall of sea level in the aftermath of a glacial-driven eustatic rise of sea level related to the regionally extended Kaigas glaciation.
The $\sim 765-715 \mathrm{Ma}$ tectonostratigraphic sequence strata of the Mwashya Subgroup in DRC, and its stratigraphic equivalent the Mwashia Subgroup in Zambia, were marked by a transgressive marine carbonate sequence, coupled with $\sim 746$ Ma volcaniclastic rocks in the Damara Belt in Namibia, that was capped by pre-rift glacial deltaic siliciclastic rock series. Consequently, the cycles of deposition could be considered as tectonosequences driven by regional tectonic controls superimposed upon climate changes that are reflected by the glacial-derived $\sim 750-720$ Ma Mwashya Conglomerate and the $740-715$ Ma Mwale Formation.

\subsection{Origin of the Mwashya Conglomerate}

At TFMD, the sedimentary features are absent in the Mwashya Conglomerate. The absence of diagnostic pore water pressure structures (flow noses, tiles structures, glaciotectonic laminations, unidirectional folding, clast dispersion tails and fracturing) and features typical of direct ice-contact deposits (boulder pavements, and common presence of striated and glacially-shaped clasts) rejects a direct glacial origin, i.e., tillites, by a high overburden pressure of ice and basal meltwater supply. The smooth and polished surfaces of clasts and the clast-roundness demonstrate an active transport, in which a significant abrasion increased the edge-rounding and the polishing of clasts. The normally graded 
sequence contains abundant debris fall sediments that show first larger particles and then fine-grained material, resembling sediment flows. The graded sequence is overlain by layered drapes of fine sediments devoid of clasts (Benn \& Evans, 2010). This vertical distribution of lithology could be interpreted as composite subaqueous "en-masse" transport deposits (sliding, slumping, debris flow, turbidity currents), here referred to as olistostromes (Festa et al., 2016). Olistostromes are produced by chaotic gravitational sliding and/or flow of semi-lithified sediments. They form sedimentary melanges of intrabasinal and/ or extrabasinal clasts in a folded and/or sheared matrix-supported conglomerates (Flores, 1955; Condie, 2005). The volcaniclastic facies embedded in the conglomerates are stratigraphically and sedimentologically consistent with sedimentary-derived mass transport deposits. The dolomitic nature and internal shear zone of the matrix indicate that liquefaction and/or fluidization processes induced stretching of the sediments along the direction of flow on a tectonically-active and uplifted carbonate platform. This deformation initiated the emplacement of "en-masse" transport of block sliding or debris flow along rifted continental edges (Ogata et al., 2014; Festa et al., 2016). With the deceleration of the flow, fine-grained material deposited as contemporaneous pelagic clays expelled from the top of the mass transport flows. At TFMD, the Mwashya Conglomerate appears to be deposited as proximal mass transport deposits derived from the carbonate platform along the fault-controlled uplifted margin of the newly formed Nguba rift-basin. Subaqueous mass transport deposits could be formed by the rapid retreat of ice and the increase of siliciclastic supply accumulated atop of an unstable edge of the slope margin. But they are not necessarily related to a glacial climate. Along the palaeoshore line, fluvio-deltaic coarse-grained and conglomeratic sediments were deposited near the Kibara Belt and pre-Kibaran basement. Fine-grained material such as polymictic conglomerates and diamictites were deposited seaward on the slope and in the basin to the south of the rifted basin. The vertical distribution of facies overlying the Mwashya Conglomerate has been interpreted as interglacial deposits between two glaciations (Cahen, 1954, 1963). Thinly bedded, finely laminated, shales embedded in feldspathic-quartzites in the Kanzadi Formation have been considered as glacial varvites and eolian sediments that were deposited before the Sturtian glaciation as evidenced by the Mwale Formation (Cahen, 1947a,b).

\subsection{Post-glacial cap carbonate sequence}

The Neoproterozoic post-glaciation is classically characterized by the occurrence of a cap carbonate sequence, and a negative excursion in carbon isotope values above a diamictite. A cap carbonate sequence is defined as laterally continuous, $10 \mathrm{~m}$ - up to 100 m-thick carbonate succession, sharply overlying Cryogenian glacial deposits, that record successively a deepening-upward transgressive system tract and a shallowing-upward highstand system tract bounded atop by a subaerial exposure surface (Shields, 2005; Hoffman et al., 2017). Considering the vertical staking patterns of this sequence, the carbonate succession of the Kamoya Formation could be considered as a cap carbonate sequence over the periglacial Mwashya Conglomerate (Fig. 12). Indeed, the Kamoya carbonate succession records an up to $100 \mathrm{~m}$-thick deepening-to-shallowing upward succession including transgressive, highstand and lowstand system tracts. At TFMD, the onset of the marine transgression was marked by an oversaturation in iron as shown by the iron-bearing polymictic conglomerate typically associated with a hematite-rich matrix. Ferrous iron was generated by volcanic activity triggered by the initial stage of the rifting of the Nguba rift-basin, which concentrated the iron in solution in bottom waters during an englacial period of basin starvation. With the seawater warming and the ice melting, the oceanic circulation initiated the mixing between the iron-rich bottom and the oxygenated surface waters, which oxidized the ferrous iron in hematite. Later, the ocean was marked at the surface by an anomalous state of carbonate oversaturation that allowed the formation of a variety of seafloor aragonitic cements, and in the shallower part the development of oolites. The distribution of these facies occurred in the Sturtian cryochron, rather than the glacial-related Kaigas sediments in the Gariep Belt. The latter differs by the absence of a near-basal

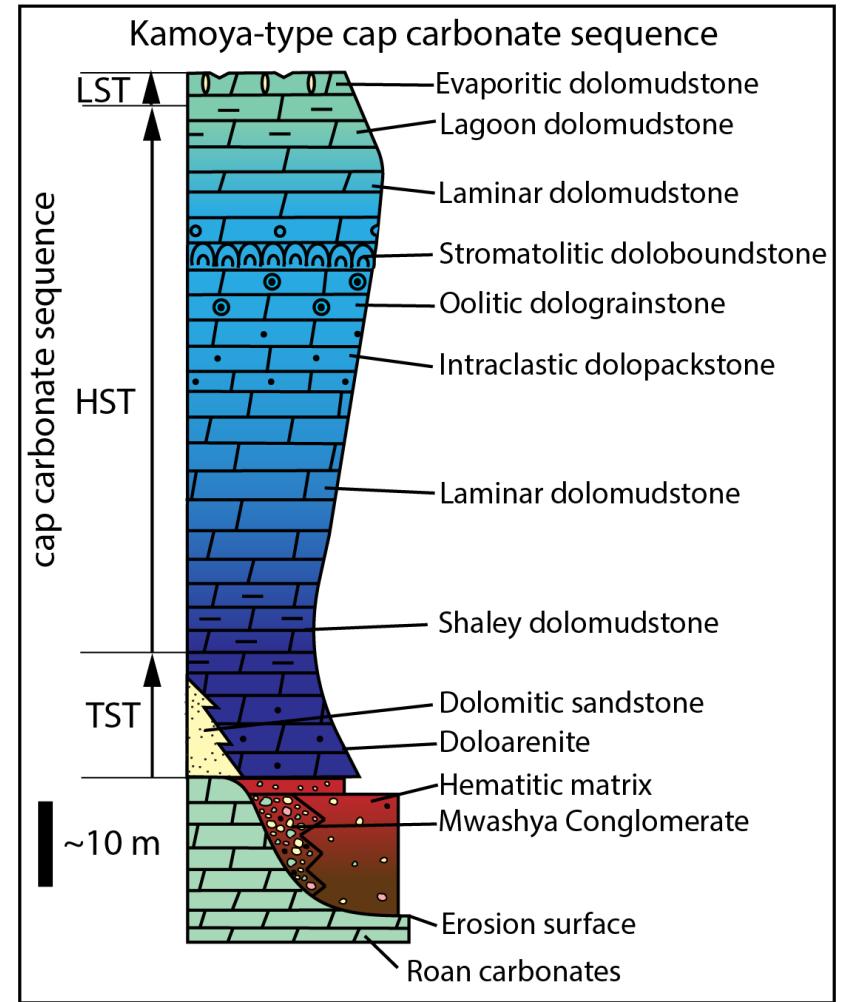

Figure 12. Idealized Kamoya cap carbonate sequence at TFMD. The cap sequence, sharply overlying Cryogenian periglacial deposits of the ironbearing Mwashya Conglomerate at the base, shows a deepening-upward transgressive system tract capped by a shallowing-upward highstand tract bounded atop by a lowstand system tract. The Mwashya Conglomerate was marked by an oversaturation in iron that was generated by volcanic activity in bottom waters during an englacial period of basin starvation. Later, the oceanic circulation initiated the mixing between the iron-rich bottom and the oxygenated surface waters, which oxidized the ferrous iron in hematite. This water mixing oversaturated in calcium the seawater that rapidly favouring the formation of oolites on the barrier platform top during a sea-level rise, followed by the development of lagoonal and tidal flat sediments during a sea-level highstand.

banded iron-formation or a ferruginous arenite zone (Frimmel, 2011; Hoffman et al., 2011; Cox et al., 2016).

In Zambia, carbon isotope values show a negative $\delta^{13} \mathrm{C}$ excursion at the boundary between the Kanwangungu Formation and the Mwashia Subgroup, which is not significant as evidence of Kaigas glaciation in the Nguba rift-basin (Bull et al., 2011). Above this boundary, $\delta^{13} \mathrm{C}$ values show an upward decreasing trend from $+5 \%$ at the base of the Mwashia Subgroup down to $-6 \%$ immediately below the Grand Conglomerate (Bull et al., 2011).

In conclusion, the Mwashya Conglomerate at TFMD records unusual depositional conditions that were controlled by regional tectonics coupled with the Kaigas glaciation event. Intermittent movements along pre-existing Kibaran faults produced regional uplift, which was rapidly eroded and formed unsorted conglomeratic-like mass transport deposits along rifted platform edges. Glacial sediments were produced on elevated uplifted blocks, that were bordered by a thin rim of palaeoshore lines fringed by a fluvio-deltaic siliciclastic system along the Kibara Belt and pre-Kibaran basement, and by a mixed siliciclasticcarbonate platform to slope marine system to the south of the rifted basin. At this time, the oceanic circulation was slowing down due to the possible impact of the Kaigas glaciation centred in the current Gariep Belt in Namibia. A widespread, large amount of ferrous iron in solution in pore water from sea-floor sediments originated from $\sim 765-740 \mathrm{Ma}$ volcanic intrusions. With the deglaciation, the oceanic circulation restarted, and upwelling currents mixed the surface water with the bottom water, oxidizing the ferrous iron resulting in the precipitation of hematite. This stage initiated a wide marine transgression of large magnitude. A 
carbonate platform and lagoon-type restricted basin developed in the Nguba rift-basin.

\subsection{Tectonic control driving the sedimentation}

The sediments deposited on slopes are usually exposed to gravity instability and overloading and sensitive to seismic shocks, which can produce soft sediment deformation structures (Owen, 2003; Moretti et al., 2001; Ge \& Zhong, 2017; Liang et al., 2016). The platform carbonate succession of the Nguba rift-basin was deposited in a tectonically active setting (Lefebvre, 1973; De Waele et al., 2008; Kampunzu et al., 2000; Bull et al., 2011; Mambwe et al., 2019a) as evidenced by seismites and other seismicallyinduced soft sediment deformation structures (see discussion in Mambwe et al., 2019a). At TFMD, slump, convolute and load deformation structures and syn-depositional faulting are observed in the Kansuki and Kamoya formations. The load deformation structures observed are induced by overloading, which resulted from high sedimentation rates in the back-barrier beach and tidal flat environment (Fig. 5c). The slump structures were formed by a down-dip pressure on the sediments, coeval with the formation of the monogenic conglomerate in the barrier shoal environment (Fig. 5b). These deposits indicate the importance of gravity flow processes during and after sedimentation, which is interpreted to be related to the extensional tectonics during the deposition of the Roan Group (Lefebvre, 1973; Selley et al., 2005, Batumike et al., 2006; Mahanjane \& Franke, 2014; Mambwe, 2017; Kennedy et al., 2019). The syn-depositional normal fault in the Kansuki Formation and the Mwashya Conglomerate at the base of the Kamoya Formation could be linked to the rift's extensional phase of the Nguba rift-basin in both DRC and Zambia. Such mass transport sedimentary deposits related to extensional tectonics are common in the Neoproterozoic and Phanerozoic basins in Central Africa (Mahanjane \& Franke, 2014; Delpomdor et al., 2016; Mambwe et al., 2017a).

Glacio-isostatic rebound could also have played a role on the sedimentation during and after the important Neoproterozoic glaciation (e.g. Van Loon et al., 2016; Pisarska-Jamroży et al., 2018; Woźniak \& Pisarska-Jamroży, 2018), and thus of the deposition of the glacially-influenced $\sim 750-720$ Ma Mwashya Conglomerate and $740-715$ Ma Mwale Formation.

\section{Conclusion}

Lithofacies and sequence stratigraphy analyses suggest that the Kansuki-Mwashya platform succession at the Tenke Fungurume Mining District, Democratic Republic of the Congo, was formed on a tectonically active carbonate platform, which occurred during the initial phase of syn-rifting of the Nguba rift-basin. The early syn-rifting phase was marked by the deposition of the Kansuki Formation in one single transgressive-to-regressive sequence that consists of fore-barrier lagoonal to lagoon/tidal flat cycles. A subsequent relative fall of sea level was marked by the back stepping from tidal flat to lagoonal facies, and the deposition of a basal iron-bearing polymictic conglomerate at the base of the Mwashya Subgroup, here attributed to the Mwashya Conglomerate, that recorded a return of fluvial discharge centred on the Kibara Belt or pre-Kibaran basement to the north of the basin. Facies analysis revealed that the Mwashya Conglomerate is an olistostrome derived from a mixed siliciclastic-carbonate platform along the fault-controlled uplifted margin, which could have been uplifted above the snowlines, of the newly formed Nguba rift-basin. With existing age constraints and the volcanic activity, a glaciogenic origin is consistent with a long-lasting Sturtian glacial period that is coeval with the $\sim 760-740 \mathrm{Ma}$ Kaigas Formation in Namibia. Considering the similarity with the Cryogenian glacial sediments, the overlying vertical stacking patterns of lithofacies observed in the Kamoya Formation is here interpreted as a cap carbonate sequence over the Mwashya Conglomerate. This cap carbonate sequence records a significant rise of sea level that was marked by an oversaturation of the seawater in calcium that promoted the production of carbonate such as oolites on the barrier platform top, and the development of lagoonal and tidal flat sediments during sea-level highstand. The Kamoya succession was preceded by the deposition of a transgressive sequence of the Kafubu Formation marked by the deposition of carbonaceous shales in a poorly oxygenated lagoon- like basin. These sediments record a third sequence of deposition at the onset of the Sturtian glaciation, marked by a cold climate and sea-level fall, coupled with the initial phase of syn-rifting of the Nguba rift-basin. This third sequence is incomplete due to the rapid erosion of scarps formed by fault-controlled uplifts during deposition of the glacially-influenced Mwale Formation. The tectonostratigraphic model presented herein suggests that the depositional cycles recognized in the Kansuki-Mwashya platform succession reflect tectonosequences that were driven by regional tectonic controls superimposed upon the long-lasting Sturtian glacial period.

\section{Acknowledgments}

The $\mathrm{PhD}$ grant for Pascal Mambwe was funded by FONDS MARC VERVENNE (KU Leuven). Authors thank Tenke Fungurume Mining SA for permission to publish the results of this research. The authors acknowledge Scott Elrick (ISGS) for helpful discussions and improving the English of the manuscript. The authors are very grateful to Prof. Dr Marek Wendorff for insightful comments and ongoing discussion. Dr Damien Delvaux and Prof. Dr Frederick Kamona are thanked for the stimulating remarks and comments, which improved this paper.

\section{References}

Alexandre, J., 2002. Les cuirasses latéritiques et autres formations ferrugineuses tropicales. Exemple du Haut Katanga méridional. Annales de Science Géologique, série in-8, Musée Royal de l'Afrique Centrale, Tervuren, Belgique, 107, 118 p.

Alexandre-Pyre, S., 1967. Les processus d'aplanissement de piémont dans les régions marginales du plateau des Biano. Publication de l'Université Officielle du Congo à Lubumbashi, 16, 3-50.

Armstrong, R.A., Robb, L.J., Master, S., Kruger, F.J. \& Mumba, P.A.C.C., 1999. New U-Pb age constraints on the Katangan Sequence, Central African Copperbelt. Journal of African Earth Sciences, 28/4, suppl. $1,6-7$.

Barron, J.W., Broughton, D.W., Armstrong, R.A. \& Hitzman, M.W., 2003. Petrology, geochemistry and age of gabbroic bodies in the Solwezi area, northwestern Zambia. Contributions presented at the $3^{\text {rd }}$ IGCP450 Conference, Proterozoic Sediment-hosted Base Metal Deposits of Western Gondwana, Conference and Field Workshop Lubumbashi 2003, Lubumbashi, Democratic Republic of Congo, 75-77.

Batumike, M.J., Kampunzu, A.B. \& Cailteux, J.H., 2006. Petrology and geochemistry of the Neoproterozoic Nguba and Kundelungu Groups, Katangan Supergroup, southeast Congo: implications for provenance, paleoweathering and geotectonic setting. Journal of African Earth Sciences, 44, 97-115. https://doi.org/10.1016/j. jafrearsci.2005.11.007

Batumike, M.J., Cailteux, J.L.H. \& Kampunzu, A.B., 2007. Lithostratigraphy, basin development, base metal deposits, and regional correlations of the Neoproterozoic Nguba and Kundelungu rock successions, central African Copperbelt. Gondwana Research, 11/3, 432-447. https://doi.org/10.1016/j.gr.2006.04.012

Benn, D.I. \& Evans, D.J.A., 2010. Glaciers \& Glaciation. $2^{\text {nd }}$ ed. Routlege, New York, 802 p.

Binda, P.L. \& Van Eden, J.G., 1972. Sedimentological evidence on the origin of the Precambrian Great Conglomerate (Kundelungu Tillite), Zambia. Palaeogeography, Palaeoclimatology, Palaeoecology, 12, 151-168. https://doi.org/10.1016/0031-0182(72)90057-0

Borg, G., Kärner, K., Buxton, M., Armstrong, R. \& Van der Merwe, S.W., 2003. Geology of the Skorpion supergene zinc deposit, southern Namibia. Economic Geology, 98, 749-771. https://doi.org/10.2113/ gsecongeo.98.4.749

Buffard, R., 1988. Un rift intracontinental du Précambrien Supérieur: le Shaba méridional (Zaïre). Evolution sédimentaire et tectonique du Supergroupe de Roan au Groupe du Kundelungu inférieur (Supergroupe du Kundelungu). Unpublished Ph.D. thesis, Université du Maine, Le Mans, France, 316 p.

Bull, S., Selley, D., Broughton, D., Hitzman, M., Cailteux, J., Large, R. \& McGoldrick, P., 2011. Sequence and carbon isotopic stratigraphy of the Neoproterozoic Roan Group strata of the Zambian Copperbelt. Precambrian Research, 190, 70-89. https://doi.org/10.1016/j. precamres.2011.07.021

Cahen, L., 1947a. A propos de formations éoliennes périglaciaires de la Série de Mwashya. Bulletin de la Société Belge de Géologie, 56, 8-16. 
Cahen, L., 1947b. Les glaciations pré-Karoo du bassin du Congo et de l'Afrique australe. Bulletin de la Société Belge de Géologie, 56, $109-152$.

Cahen, L., 1954. Géologie du Congo Belge. Vaillant-Carmanne, Liège, 577 p.

Cahen, L., 1963. Glaciations anciennes et dérive des continents. Annales de la Société Géologique de Belgique, 86, B19-B84.

Cailteux, J., 1983. Le Roan shabien dans la région de Kambove (ShabaZaïre). Etude sédimentologique et métallogénique. Unpublished Ph.D. thesis, Université de Liège, Liège.

Cailteux, J., 1994. Lithostratigraphy of the Neoproterozoic Shabatype (Zaïre) Roan Supergroup and metallogenesis of associated stratiform mineralization. In Kampunzu, A.B. \& Lubala, R.T. (eds), Neoproterozoic Belts of Zambia, Zaire and Namibia. Journal of African Earth Sciences, 19, 279-301. https://doi.org/10.1016/08995362(94)90015-9

Cailteux, J.L.H. \& De Putter, T., 2019. The Neoproterozoic Katanga Supergroup (D.R. Congo): State-of-the-art and revisions of the lithostratigraphy, sedimentary basin and geodynamic evolution. Journal of African Earth Sciences, 150, 522-531. https://doi. org/10.1016/j.jafrearsci.2018.07.020

Cailteux, J. \& Kampunzu, A.B., 1995. The Katangan tectonic breccias in the Shaba province (Zaire) and their genetic significance. In Wendorff, M. \& Tack, L. (eds), Late Proterozoic Belts in Central and Southwestern Africa. Annales du Musée Royal de l'Afrique Centrale, Tervuren, Belgique, Sciences géologiques, 101, 63-76.

Cailteux, J., Binda, P.L., Katekesha, W.M., Kampunzu, A.B., Intiomale, M.M., Kapenda, D., Kaunda, C., Ngongo, K., Tshiauka, T. \& Wendorff, M., 1994. Lithostratigraphical correlation of the Neoproterozoic Roan Supergroup from Shaba (Zaïre) and Zambia, in the Central African copper-cobalt metallogenic province. In Kampunzu, A.B. \& Lubala, R.T. (eds), Neoproterozoic Belts of Zambia, Zaire and Namibia. Journal of African Earth Sciences, 19, 265-278. https://doi.org/10.1016/0899-5362(94)90014-0

Cailteux, J.L.H., Kampunzu, A.B.H. \& Batumike, M.J., 2005. Lithostratigraphic position and petrographic characteristics of R.A.T. ("Roches Argilo-Talqueuses") Subgroup, Neoproterozoic Katanga Belt (Congo). Journal of African Earth Sciences, 42, 82-94. https:// doi.org/10.1016/j.jafrearsci.2005.08.011

Cailteux, J.L.H., Kampunzu, A.B. \& Lerouge, C., 2007. The Neoproterozoic Mwashya-Kansuki sedimentary rock succession in the central African Copperbelt, its $\mathrm{Cu}-\mathrm{Co}$ mineralization, and regional correlations. Gondwana Research, 11, 414-431. https://doi. org/10.1016/j.gr.2006.04.016

Cailteux, J.L.H., Muchez, P., De Cuyper, J., Dewaele, S., De Putter, T., 2018. Origin of the megabreccias in the Katanga Copperbelt (D.R. Congo). Journal of African Earth Sciences, 140, 76-93. https://doi. org/10.1016/j.jafrearsci.2017.12.029

Catuneanu, O., 2006. Principles of sequence stratigraphy. Elsevier, Amsterdam, $375 \mathrm{p}$.

Catuneanu, O., Galloway, W.E., Kendall, C.G.S.C., Miall, A.D., Posamentier, H.W., Strasser, A. \& Tucker, M.E., 2011. Sequence stratigraphy: methodology and nomenclature. Newsletters on Stratigraphy, 44, 173-245. https://doi.org/10.1127/00780421/2011/0011

Condie, K.C., 2005. Earth as an Evolving Planetary System. Elsevier Academic Press, Amsterdam, 447 p.

Cox, G.M., Halverson, G.P., Poirier, A., Le Heron, D., Strauss, J.V. \& Stevenson, R., 2016. A model for Cryogenian iron formation. Earth and Planetary Science Letters, 433, 280-292. https://doi. org/10.1016/j.eps1.2015.11.003

Delpomdor, F., Eyles, N., Tack, L. \& Préat, A., 2016. Pre- and postMarinoan carbonate facies of the Democratic Republic of the Congo: glacially- or tectonically influenced deep-water sediments? Palaeogeography, Palaeoclimatology, Palaeoecology, 457, 144-157. https://doi.org/10.1016/j.palaeo.2016.06.014

De Magnée, I. \& François, A., 1988. The origin of the Kipushi $(\mathrm{Cu}, \mathrm{Zn}$, $\mathrm{Pb}$ ) deposit in direct relation with a Proterozoic salt diapir. Copperbelt of Central Africa, Shaba, Republic of Zaire. In Friedrich, G.H. \& Herzig, P.M. (eds), Base Metal Sulfide Deposits in Sedimentary and Volcanic Environments. Springer, Berlin, 74-93.

De Waele, B., Johnson, S.P. \& Pisarevsky, S.A., 2008. Palaeoproterozoic to Neoproterozoic growth and evolution of the eastern Congo Craton: Its role in the Rodinia puzzle. Precambrian Research, 160, 127-141. https://doi.org/10.1016/j.precamres.2007.04.020
Dunham, R.J., 1962. Classification of carbonate rocks according to depositional texture. In Ham, W.E. (ed.), Classification of Carbonate Rocks. AAPG Memoir, 1, 108-121.

Embry, A.F. \& Klovan, J.E., 1972. Absolute water depth limits of late Devonian paleoecological zones. Geologische Rundschau, 61, 672686. https://doi.org/10.1007/BF01896340

Festa, A., Ogata, K., Pini, G.A., Dilek, Y. \& Alonso, J.L., 2016. Origin and significance of olistostromes in the evolution of orogenic belts: A global synthesis. Gondwana Research, 39, 180-203. https://doi. org/10.1016/j.gr.2016.08.002

Flores, G., 1955. Les résultats des études pour les recherches pétrolifères en Sicile: Discussion. Proceedings of the $4^{\text {th }}$ World Petroleum Congress, Casa Editrice Carlo Colombo, Rome, 121-122.

Flügel, E., 2010. Microfacies of Carbonate Rocks, Analysis Interpretation and Application. Springer, Berlin, 984 p. https://oi.org/10.1007/978 3-642-03796-2

Fölling, P.G., Zartman, R.E. \& Frimmel, H.E., 2000. A novel approach to double-spike $\mathrm{Pb}-\mathrm{Pb}$ dating of carbonate rocks: examples from Neoproterozoic sequences in southern Africa. Chemical Geology, 171, 97-122. https://doi.org/10.1016/S0009-2541(00)00204-7

François, A., 1987. Synthèse géologique sur l'arc cuprifère du Shaba (Rép. du Zaïre). Centenaire de la Société Belge de Géologie, 15-65.

François, A., 2006. La partie centrale de l'Arc cuprifère du Katanga: étude géologique. Tervuren African Geoscience Collection, 109, 61 p.

Frimmel, H.E., 2009a. Configuration of Pan-African orogenic belts in Southwestern Africa. In Gaucher, C., Sial, A.N., Halverson, G.P. \& Frimmel, H.E. (eds), Neoproterozoic-Cambrian Tectonics, Global Change and Evolution: A Focus on south western Gondwana Elsevier, Amsterdam, Developments in Precambrian Geology, 16, 145-151. https://doi.org/10.1016/S0166-2635(09)01610-7

Frimmel, H.E., 2009b. Trace element distribution in Neoproterozoic carbonates as palaeoenvironmental indicator. Chemical Geology, 258, 338-353. https://doi.org/10.1016/j.chemgeo.2008.10.033

Frimmel, H., 2011. The Kaigas and Numees formations, Port Nolloth Group, in South Africa and Namibia. In Arnaud, E., Halverson, G.P. \& Shields-Zhou, G. (eds), The Geological Record of Neoproterozoic Glaciations. Geological Society, London, Memoirs, 36, 223-231. https://doi.org/10.1144/M36.17

Frimmel, H. E., Klötzli, U. \& Siegfried, P., 1996. New Pb-Pb single zircon age constraints on the timing of Neoproterozoic glaciation and continental break-up in Namibia. Journal of Geology, 104, 459-469. https://doi.org/10.1086/629839

Frimmel, H.E., Zartman, R.E. \& Späth, A., 2001. The Richtersveld Igneous Complex, South Africa: U-Pb zircon and geochemical evidence for the beginning of Neoproterozoic continental breakup. Journal of Geology, 109, 493-508. https://doi.org/10.1086/320795

Ge, Y. \& Zhong, J., 2017. Trigger recognition of Early Cretaceous softsediment deformation structures in a deep-water slope-failure system. Geology Journal, 53, 2633-2648. https://doi.org/10.1002/gj.3101

Grabau, A.W., 1904. On the classification of sedimentary rocks. The American Geologist, 33, 228-247.

Halpin, J. \& Selley, D., 2010. Insights to geometry and structural evolution of the Central African Copperbelt from zircon provenance analysis: Sediment-hosted copper deposits of Congolese, Zambian, and central Australian basin systems. Meeting of CODES-CSM AMIRA P872 Project, Final report, 33-47.

Halverson, G.P., Hoffman, P.F., Schrag, D.P., Maloof, A.C. \& Rice, A.H.N., 2005. Toward a Neoproterozoic composite carbon-isotope record. Geological Society of America Bulletin, 117, 1181-1207. https://doi.org/10.1130/B25630.1

Hoffman, P.F., Hawkins, D.P., Isachsen, C.E. \& Bowring, S.A., 1996 Precise $\mathrm{U}-\mathrm{Pb}$ zircon ages for early Damaran magmatism in the Summas Mountains and Welwitschia Inlier, northern Damara belt, Namibia. Communication of Geological Survey of Namibia, 11, 47-52.

Hoffman, P.F., Macdonald, F.A. \& Halverson, G.P., 2011. Chemical sediments associated with Neoproterozoic glaciation: Iron formation, cap carbonate, barite and phosphorite. In Arnaud, E., Halverson, G.P. \& Shields-Zhou, G. (eds), The Geological Record of Neoproterozoic Glaciations. Geological Society, London, Memoirs, 36, 67-80. https://doi.org/10.1144/M36.5 
Hoffman, P.F., Abbot, D.S., Ashkenazy, Y., Benn, D.I., Brocks, J.J., Cohen, P.A., Cox, G.M., Creveling, J.R., Donnadieu, Y., Erwin, D.H., Fairchild, I.J., Ferreira, D., Goodman, J.C., Galverson, G.P., Jansen, M.F., Le Hir, G., Love, G.D., Macdonald, F.A., Maloof, A.C., Partin, C.A., Ramstein, G., Rose, B.E.J., Rose, C.V., Sadler, P.M., Tziperman, E., Voigt, A. \& Warren, S.G., 2017. Snowball Earth climate dynamics and Cryogenian geology-geobiology. Science Advances 3, e1600983. https://doi.org/10.1126/sciadv.1600983

Hsü, K.J., 1974. Melanges and their distinction from olistostromes. In Dott, R.H.Jr. \& Shaver, R.H. (eds), Modern and Ancient Geosynclinal Sedimentation. SEPM Special Publication, 19, 321-333. https://doi. org/10.2110/pec.74.19.0321

Jackson, M.P.A., Warin, O.N., Woad, G.M. \& Hudec, M.R., 2003. Neoproterozoic allochthonous salt tectonics during the Lufilian orogeny in the Katangan Copperbelt, central Africa. Geological Society of America Bulletin, 115, 314-330. https://doi. org/10.1130/0016-7606(2003)115<0314:NASTDT>2.0.CO;2

John, T., Schenk, V., Mezger, K. \& Tembo, F., 2004. Timing and PT evolution of whiteschist metamorphism in the Lufilian Arc-Zambezi belt orogen (Zambia): implications for the assembly of Gondwana. Journal of Geology, 112, 71-90. https://doi.org/10.1086/379693

Johnson, S.P., De Waele, B., Evans, D., Banda, W., Tembo, F., Milton, J.A. \& Tani, K., 2007. Geochronology of the Zambezi Supracrustal Sequence, Southern Zambia: A record of Neoproterozoic divergent processes along the southern margin of the Congo Craton. Journal of Geology, 115, 355-374. https://doi.org/10.1086/512757

Jones, B.W. \& Desrochers, A., 1992. Shallow platform carbonates. In Walker, R.G. \& James, N.P. (eds), Facies models. Geology Association of Canada, St. John's, Nfld, 277-301.

Kampunzu, A.B. \& Cailteux, J., 1999. Tectonic evolution of the Lufilian arc (Central Africa Copper Belt) during Neoproterozoic Pan African orogenesis. Gondwana Research, 2, 401-421. https://doi. org/10.1016/S1342-937X(05)70279-3

Kampunzu, A.B., Tembo, F., Matheis, G., Kapenda, D. \& HuntsmanMapila, P., 2000. Geochemistry and tectonic setting of mafic igneous units in the Neoproterozoic Katangan Basin, Central Africa: implication for Rodinia break-up. Gondwana Research, 3, 125-153. https://doi.org/10.1016/S1342-937X(05)70093-9

Kampunzu, A.B., Cailteux, J.L.H., Moine, B. \& Loris, H.N.B.T., 2005. Geochemical characterisation, provenance, source and depositional environment of 'Roches Argilo-Talqueuses' (RAT) and Mines Subgroups sedimentary rocks in the Neoproterozoic Katangan Belt (Congo): Lithostratigraphic implications. Journal of African Earth Sciences, 42, 119-133. https://doi.org/10.1016/j. jafrearsci.2005.08.003

Kennedy, K., Eyles, N. \& Broughton, D., 2019. Basinal setting and origin of thick $(1.8 \mathrm{~km})$ mass-flow dominated Grand Conglomérat diamictites, Kamoa, Democratic Republic of Congo: resolving climate and tectonic controls during Neoproterozoic glaciations. Sedimentology, 66, 556-589. https://doi.org/10.1111/sed.12494

Key, R.M., Liyungu, A.K., Njamu, F.M., Somwe, V., Banda, J., Mosley, P.N. \& Armstrong, R.A., 2001. The western arm of the Lufilian Arc in NW Zambia and its potential for copper mineralization. Journal of African Earth Sciences, 33, 503-528. https://doi.org/10.1016/S08995362(01)00098-7

Kipata, M.L., Delvaux, D., Sebagenzi, M.N., Cailteux, J. \& Sintubin, M., 2013. Brittle tectonic and stress field evolution in the PanAfrican Lufilian arc and its foreland (Katanga, DRC): from orogenic compression to extensional collapse, transpressional inversion and transition to rifting. Geologica Belgica, 16, 1-17.

Lefebvre, J.J., 1973. Présence d'une sédimentation pyroclastique dans le Mwashia inférieur du Shaba méridional (ex Katanga). Annales de la Société Géologique de Belgique, 96, 197-217.

Lefebvre, J.J., 1976. Le contact entre le Kundelungu et le Roan à Mulungwishi, Shaba, Zaïre. Annales de la Société Géologique de Belgique, 99, 451-466.

Lefebvre, J.J., 1978. Le Groupe de Mwashya. Megacyclothème terminal du Roan (Shaba, Zaïre sud-oriental). I Approche lithostratigraphique et étude de l'environnement sédimentaire. Annales de la Société Géologique de Belgique, 101, 209-225.

Liang, Z., Zhou, Y. \& Van Loon, T., 2017. Soft-sediment deformation structures induced by rapid sedimentation in Early Cretaceous turbidites, Lingshan Island, eastern China. Canadian Journal of Earth Science, 55, 118-129. https://doi.org/10.1139/cjes-2017-0106
Mahanjane, E. S. \& Franke, D., 2014. The Rovuma Delta deep-water fold-and-thrust belt, offshore Mozambique. Tectonophysics, 614, 91-99. https://doi.org/10.1016/j.tecto.2013.12.017

Mambwe, P., 2017. Sédimentologie et minéralisation cuprifère associée au Groupe du Kundelungu. Cas du gisement de Shangoluwe (Kambove, RDC). Inclusions fluides et contrôle tectonique. Unpublished MSc. Thesis, University of Lubumbashi, DRC, 132 p. https://doi. org/10.13140/RG.2.2.14977.81766

Mambwe, P., Milan, L., Batumike, J., Lavoie, S., Jébrak, M., Kipata, L., Chabu, M., Mulongo, S., Lubala, T., Delvaux, D. \& Muchez, $\mathrm{Ph}$., 2017a. Lithology, petrography and $\mathrm{Cu}$ mineralisation of the Neoproterozoic glacial Mwale Formation at the Shanika Syncline (Tenke Fungurume, Congo copperbelt; democratic Republic of Congo). Journal of African Earth Sciences, 129, 898-909. https://doi. org/10.1016/j.jafrearsci.2017.02.021

Mambwe, P., Kipata, M.L., Chabu, M., Muchez, Ph., Lubala, R. T., Jébrak, M. \& Delvaux, D., 2017b. Sedimentology of the Shangoluwe breccias and timing of the $\mathrm{Cu}$ mineralization (Katanga Supergroup, D. R. of Congo). Journal of African Earth Sciences, 132, 1-15. https://doi.org/10.1016/j.jafrearsci.2017.04.017

Mambwe, M., Lavoie, S., Delvaux, D. \& Batumike, J.M., 2019a. Soft sediment deformation structures in the Neoproterozoic Kansuki formation (Katanga Supergroup, Democratic Republic of the Congo): Evidence for deposition in a tectonically active carbonate platform. Journal of African Earth Sciences, 150, 86-95. https://doi. org/10.1016/j.jafrearsci.2018.09.002

Mambwe, P., Muchez, Ph., Lavoie, S., Kipata, L. \& Dewaele, S., 2019 b. Evidence for late Lufilian orogenic mineralizing fluids at the Kamalondo Cu-Co deposit (Tenke Fungurume, Democratic Republic of the Congo). Proceedings of the $15^{\text {th }}$ SGA Biennial Meeting, 27-30 August 2019, Glasgow, Scotland, 287-290.

Master, S. \& Wendorff, M., 2011. Neoproterozoic diamictites of the Katanga Supergroup, Central Africa. In Arnaud, E., Halverson, G.P. \& Shields-Zhou, G. (eds), The Geological Record of Neoproterozoic Glaciations. Geological Society, London, Memoirs, 36, 173-184. https://doi.org/10.1144/M36.12

Master, S., Rainaud, C., Armstrong, R.A., Phillips, D. \& Robb, L.J., 2003. Provenance ages of the Neoproterozoic Katanga Supergroup (Central African Copperbelt), based on SHRIMP U-Pb and laser ${ }^{40} \mathrm{Ar} /{ }^{39} \mathrm{Ar}$ dating of detrital zircons and muscovites, with implications for basin evolution. Economic Geology Research Institute, University of the Witwatersrand, Johannesburg, Information Circular, 376, 33 p.

Master, S., Rainaud, C., Armstrong, R.A., Phillips, D. \& Robb, L.J., 2005. Provenance ages of the Neoproterozoic Katanga Supergroup (Central African Copperbelt), with implications for basin evolution. Journal of African Earth Sciences, 42, 41-60. https://doi.org/10.1016/j. jafrearsci.2005.08.005

Miall, A.D., 2010. The Geology of Stratigraphic Sequences. $2^{\text {nd }}$ ed. Springer, Berlin. https://doi.org/10.1007/978-3-642-05027-5

Miller, R.McG., 2013. Comparative stratigraphic and geochronological evolution of the Northern Damara Supergroup in Namibia and the Katanga Supergroup in the Lufilian Arc of Central Africa. Geoscience Canada, 40, 118-140. https://doi.org/10.12789/geocanj.2013.40.007

Moretti, M., Soria, J., Alfaro, P. \& Walsh, N., 2001. Asymmetrical softsediment deformation structures triggered by rapid sedimentation in turbiditic deposits (Late Miocene, Guadix Basin, southern Spain). Facies, 44, 283-294. https://doi.org/10.1007/BF02668179

Ogata, K., Mountjoy, J.J., Pini, G.A., Festa, A. \& Tinterri, E., 2014. Shear zone liquefaction in mass transport deposit emplacement: a multiscale integration of seismic reflection and outcrop data. Marine Geology, 356, 50-64. https://doi.org/10.1016/j.margeo.2014.05.001

Owen, G., 2003. Load structures: gravity-driven sediment mobilization in the shallow subsurface. Geological Society, London, Special Publications, 216, 21-34. https://doi.org/10.1144/GSL. SP.2003.216.01.03

Pisarska-Jamroży, M, Belzyt, S., Börner, A. \& Hoffmann, G., Hüneke, H., Kenzler, M., Obst, K., Rother, H. \& van Loon, A.J., 2018. Evidence from seismites for glacio-isostatically induced crustal faulting in front of an advancing land-ice mass (Rügen Island, SW Baltic Sea). Tectonophysics, 745, 338-348. https://doi.org/10.1016/j. tecto.2018.08.004 
Porada, H. \& Berhorst, V., 2000. Towards a new understanding of the Neoproterozoic-Early Palaeozoic Lufilian and northern Zambezi Belts in Zambia and the Democratic Republic of Congo. Journal of African Earth Sciences, 30, 727-771. https://doi.org/10.1016/S08995362(00)00049-X

Posamentier, H.W. \& Allen, G.P., 1999. Siliciclastic sequence stratigraphy: concepts and applications. SEPM Concepts in Sedimentology and Paleontology, 7, 210 p. https://doi.org/10.2110/csp.99.07

Reineck, H.E. \& Singh, I.B., 1980. Depositional Sedimentary Environments. $2^{\text {nd }}$ ed. Springer, Berlin, 549 p.

Rooney, A.D., Strauss, J.V., Brandon, A.D. \& Mcdonald, F.A., 2015. A Cryogenian chronology: Two long-lasting synchronous Neoproterozoic glaciations. Geology, 43, 459-462. https://doi. org/10.1130/G36511.1

Schlager, W., 1993. Accommodation and supply - a dual control on stratigraphic sequences. Sedimentary Geology, 86, 111-136. https:// doi.org/10.1016/0037-0738(93)90136-S

Schuh, W., Leveille, R.A., Fay, I. \& North, R., 2012. Geology of the Tenke-Fungurume Sediment-Hosted Strata-Bound Copper-Cobalt District, Katanga, Democratic Republic of Congo. Society of Economic Geologists, Special Publication, 16, 269-301. https://doi. org/10.5382/SP.16.12

Selley, D., Broughton, D., Scott, R., Hitzman, M., Bull, S., Large, R., McGolrick, P., Croaker, M., Pollington, N. \& Barra, F., 2005. A new look at the geology of the Zambian Copperbelt. In Hedenquidt, J.W., Thompson, J.F.H., Goldfarb, R.J. \& Richards, J.P. (eds), Economic Geology: One Hundredth Anniversary Volume. Society of Economic Geologists, Littleton, CO, 965-1000. https://doi.org/10.5382/ AV100.29

Shields, G.A., 2005. Neoproterozoic cap carbonates: A critical appraisal of existing models and the plumeworld hypothesis. Terra Nova, 17, 299-310. https://doi.org/10.1111/j.1365-3121.2005.00638.x

Spence, G.H. \& Tucker, M.E., 2007. A proposed integrated multi-signature model for peritidal cycles in carbonates. Journal of Sedimentary Research, 77, 797-808. https://doi.org/10.2110/jsr.2007.080

Stoffers, P. \& Ross, D.A., 1979. Late Pleistocene and Holocene sedimentation in the Persian Gulf - Gulf of Oman. Sedimentary Geology, 23, 181-208. https://doi.org/10.1016/0037-0738(79)90014-

Twite, F., Broughton, D, Nex, P., Kinnaird, J., Gilchrist, G. \& Edwards, D., 2019. Lithostratigraphic and structural controls on sulphide mineralisation at the Kamoa copper deposit, Democratic Republic of Congo. Journal of African Earth Sciences, 151, 212-224. https://doi. org/10.1016/j.jafrearsci.2018.12.016

Van Loon, A.J.T., Pisarska-Jamroży, M., Narti, M., Kriev, M. \& Soms, J., 2016. Seismites resulting from high frequency, high-magnitude earthquakes in Latvia caused by Late Glacial glacio-isostatic uplift. Journal of Palaeogeography, 5, 363-380. https://doi.org/10.1016/j. jop.2016.05.002

Vanden Brande, P., 1932. Le conglomérat de la série de Mwashya. Annales du Service des Mines, Comité Spécial du Katanga, 3, 72-78.

Vanden Brande, P., 1944. Nouvelles observations sur le conglomérat de Mwashya et le Petit Conglomérat du Kundelungu. Comité Spécial du Katanga, Elisabethville, 12 p.

Wanless, H.R. \& Tedesco, L.P., 1993. Comparison of oolitic sand bodies generated by tidal vs. wind-wave agitation. In Keith, B.D. \& Zuppmann, C.W. (eds), Mississippian Oolites and Modern Analogs. AAPG Studies in Geology, 35, 199-225. https://doi.org/10.1306/ St35571C15

Wendorff, M., 2000. Genesis aspects of the Katangan megabreccias: Neoproterozoic of central Africa. Journal of African Earth Sciences, 30, 703-715. https://doi.org/10.1016/S0899-5362(00)00047-6

Wendorff, M., 2005a. Evolution of Neoproterozoic-Lower Palaeozoic Lufilian Arc, Central Africa: a model based on syntectonic conglomerates. Geological Society, London, Special Publications, 162, 5-8. https://doi.org/10.1144/0016-764904-085

Wendorff, M., 2005b. Sedimentary genesis and lithostratigraphy of Neoproterozoic megabreccia from Mufulira, Copperbelt of Zambia. Journal of African Earth Sciences, 42, 61-81. https://doi. org/10.1016/j.jafrearsci.2005.08.010

Wendorff, R. \& Key, R.M., 2009. The relevance of the sedimentary history of the Grand Conglomerat Formation (Central Africa) to the interpretation of the climate during a major Cryogenian glacial event. Precambrian Research, 172, 127-142. https://doi.org/10.1016/j. precamres.2009.03.013
Woźniak, P.P. \& Pisarska-Jamroży, M., 2018. Debris flows with softsediment clasts in a Pleistocene glaciolacustrine fan (Gdańsk Bay, Poland). Catena, 165, 178-191. https://doi.org/10.1016/j. catena.2018.01.022
Manuscript received 30.11.2019, accepted in revised form 05.05.2020, available online 04.07.2020. 